\title{
Silsesquioxane-bonded zirconocene complexes; soluble models for silica-tethered olefin polymerization catalysts $\uparrow$
}

\author{
John R. Severn, ${ }^{a}$ Robbert Duchateau, ${ }^{* a}$ Rutger A. van Santen, ${ }^{b}$ Dianne D. Ellis, ${ }^{c}$ \\ Anthony L. Spek ${ }^{c}$ and Glenn P. A. Yap ${ }^{d}$ \\ ${ }^{a}$ Department of Polymer Chemistry/Dutch Polymer Institute, \\ Eindhoven University of Technology, P.O. Box 513, 5600 MB Eindhoven, The Netherlands \\ ${ }^{b}$ Schuit Institute of Catalysis, Eindhoven University of Technology, P.O. Box 513, \\ $5600 \mathrm{MB}$ Eindhoven, The Netherlands \\ ${ }^{c}$ Department of Crystal and Structural Chemistry, Utrecht University, Padualaan 8 , \\ 3584 CH Utrecht, The Netherlands \\ ${ }^{d}$ University of Ottawa, K1N 6N5 Ottawa, Ontario, Canada
}

Received 17th January 2003, Accepted 10th April 2003

First published as an Advance Article on the web 29th April 2003

Silsesquioxane tethered fluorene ligands $\left[\mathrm{R}_{7} \mathrm{Si}_{8} \mathrm{O}_{12} \mathrm{X}\right]-9-\mathrm{Flu}(\mathrm{H})\left(\mathrm{R}=c-\mathrm{C}_{6} \mathrm{H}_{11}, \mathrm{X}=-(\mathbf{1}) ; \mathrm{R}=c-\mathrm{C}_{5} \mathrm{H}_{9}, \mathrm{X}=\mathrm{CH}_{2}(\mathbf{2})\right.$, $\left.\left(\mathrm{CH}_{2}\right)_{3}(3), \mathrm{C}_{6} \mathrm{H}_{4} \mathrm{CH}_{2}(4)\right),\left(c-\mathrm{C}_{5} \mathrm{H}_{9}\right)_{7} \mathrm{Si}_{8} \mathrm{O}_{12} \mathrm{CH}_{2}-9-\mathrm{Flu}\left(9-\mathrm{EMe}_{3}\right)(\mathrm{E}=\mathrm{Si}(\mathbf{5 a}), \mathrm{Sn}(\mathbf{5 b}))$ and zirconium dichlorides $\mathrm{Cp}^{\prime \prime}\left[\left(c-\mathrm{C}_{5} \mathrm{H}_{9}\right)_{7} \mathrm{Si}_{8} \mathrm{O}_{12} \mathrm{CH}_{2}-9-\mathrm{Flu}\right] \mathrm{ZrCl}_{2}\left(6 \mathbf{b}, \mathrm{Cp}^{\prime \prime}=1,3-\mathrm{C}_{5} \mathrm{H}_{3}\left(\mathrm{SiMe}_{3}\right)_{2}\right), \mathrm{Cp}^{*}\left[\left(c-\mathrm{C}_{5} \mathrm{H}_{9}\right)_{7} \mathrm{Si}_{8} \mathrm{O}_{12}-\mathrm{X}-9-\mathrm{Flu}_{2} \mathrm{ZrCl}_{2}\left(\mathrm{X}=\mathrm{CH}_{2}\right.\right.$ (6a), $\left.\left(\mathrm{CH}_{2}\right)_{3}(7), \mathrm{C}_{6} \mathrm{H}_{4} \mathrm{CH}_{2}(8)\right)$ and $\left[\left(c-\mathrm{C}_{5} \mathrm{H}_{9}\right)_{7} \mathrm{Si}_{8} \mathrm{O}_{12} \mathrm{CH}_{2}-9-\mathrm{Flu}\right]_{2} \mathrm{ZrCl}_{2}(9)$ have been applied as models for silicatethered ancillary ligands and silica tethered-zirconocenes. Immobilization of zirconocenes containing a pendant anchorable functionality, $\mathrm{Cp}^{\prime \prime}\left[\mathrm{Me}_{2}(\mathrm{EtO}) \mathrm{SiCH}_{2} \mathrm{Flu}\right] \mathrm{ZrCl}_{2}(\mathbf{1 0})$ and $\mathrm{Cp}\left[\mathrm{C}_{5} \mathrm{Me}_{4} \mathrm{SiMe}_{2} \mathrm{OEt}\right] \mathrm{ZrCl}_{2}(\mathbf{1 1})$ was considerably hampered by competitive $\mathrm{Zr}-\mathrm{Cl}$ and $\mathrm{Si}-\mathrm{OEt}$ bond splitting. When activated with MAO (methylalumoxane), 6-9 yield active ethylene polymerization systems.

\section{Introduction}

At present there is considerable academic and commercial interest in the immobilization of well-defined homogeneous olefin polymerization catalysts. ${ }^{1}$ The goal is to marry the advantages of homogeneous catalysts with those of heterogeneous ones. $^{2}$ Homogeneous catalysts are well-defined, single-site catalysts that can be fine-tuned to produce tailor-made polymers. ${ }^{3}$ Heterogeneous catalysts, however, have the technologic advantages of good morphology control, high polymer bulk density and lack of reactor fouling. ${ }^{2}$ Since most of the existing polymerization plants run as slurry or gas phase processes with heterogeneous catalyst, homogeneous catalysts must be heterogenized on a support for their application in these processes.

One of the most common methods to immobilize the catalytic system consists of physisorption of metallocenes on a silica support that is pretreated with $\mathrm{MAO}{ }^{4}$ Whereas this method results in heterogeneous catalysts, leaching and loss of activity are persistent problems. ${ }^{4}$ Consequently, improvement of this and alternative immobilization techniques, such as (co)catalyst grafting ${ }^{5,6}$ and tethering, ${ }^{7,8}$ remains a topic of great importance. Chemical tethering of organometallic compounds is, with respect to leaching, probably the best method to anchor a homogeneous catalyst to the support. Although it is the most laborious route, tethering is a versatile method to anchor virtually any homogeneous catalysts onto oxide or polymer supports, and is gaining more and more attention in the recent literature. $^{7-9}$

While several studies on tethering of olefin polymerization catalysts to silicas are reported, only little information is available on the effectiveness of the applied immobilization method as well as the steric and electronic effects of the support on these immobilized catalysts. Suitable homogeneous model systems for silica surface silanol sites, such as (poly)siloxides ${ }^{10}$

$\dagger$ Electronic supplementary information (ESI) available: ${ }^{1} \mathrm{H},{ }^{13} \mathrm{C}\{1 \mathrm{H}\}$ and ${ }^{29} \mathrm{Si}\{1 \mathrm{H}\}$ NMR data of silsesquioxane compounds $(\mathbf{1}-\mathbf{5 a} / \mathbf{b}=$ $\left.\mathrm{CDCl}_{3}, \mathbf{6}-\mathbf{9}=\mathrm{C}_{6} \mathrm{D}_{6}\right)($ Table $\mathrm{S} 1)$; crystal data for $\mathbf{1}, \mathbf{5 b}$, and $\mathbf{6} \mathbf{b}$ (Table S2) and experimental section for compounds $\mathbf{4}, \mathbf{5 b}$, and $\mathbf{6 b}$ and crystal structure analysis of $\mathbf{1}, \mathbf{5 b}$, and $\mathbf{6 b}$. See http://www.rsc.org/suppdata/dt/ $\mathrm{b} 3 / \mathrm{b} 300698 \mathrm{k} /$ and silsesquioxanes, ${ }^{11}$ could provide more insight in the stability and possible leaching processes. In the past, silsesquioxanes have successfully been used to model various silica surface silanol sites, ${ }^{11}$ group 13 element doped silicas, ${ }^{12}$ silica-grafted perfluoroborato cocatalysts, ${ }^{13}$ surface-supported (half-)metallocenes and organometallic complexes, ${ }^{14}$ and traditional heterogeneous (Ziegler-Natta and Phillips type) olefin polymerization catalysts (Fig. 1). ${ }^{15}$ We argued that these model supports could also be useful $(i)$ to optimize the synthetic strategies for preparing chemically tethered systems, (ii) to assess the electronic and local steric interactions of the tethered catalyst with the support and (iii) to understand the effect of different spacers between catalyst and support applied.

There are two general routes applied to prepare chemically tethered catalyst systems: building-up the ligand and subsequently the metal complex at the surface, ${ }^{7}$ and immobilization of a pre-synthesized catalyst precursor containing an anchorable functionality. ${ }^{8}$ Both routes clearly have their limitations and advantages.

Using silsesquioxane model supports, we tried to explore the advantages and drawbacks of both approaches. The intention was to optimize the synthetic procedures for silica-tethered metallocene catalysts as well as to study what steric and electronic effect the silsesquioxane, and hence the silica support, has on the catalytic activity of the pre-catalysts generated from these tethered ancillary ligands. Part of this work has been communicated. ${ }^{16}$

\section{Results}

\section{Silsesquioxane-tethered fluorenyl ligands}

Four silsesquioxane-tethered fluorene ligands with different spacers have been synthesized; three with a varying number $(0,1,3)$ of methylene units, and one with the more rigid benzyl spacer between the silsesquioxane and the C9 carbon of the fluorene. Several different immobilization protocols have been attempted on the homogeneous models to obtain the optimum reaction conditions to use on a silica support. The most commonly applied method to tether organic substituents onto silica surfaces is by treating the silica with tris(alkoxy)silyl functional- 

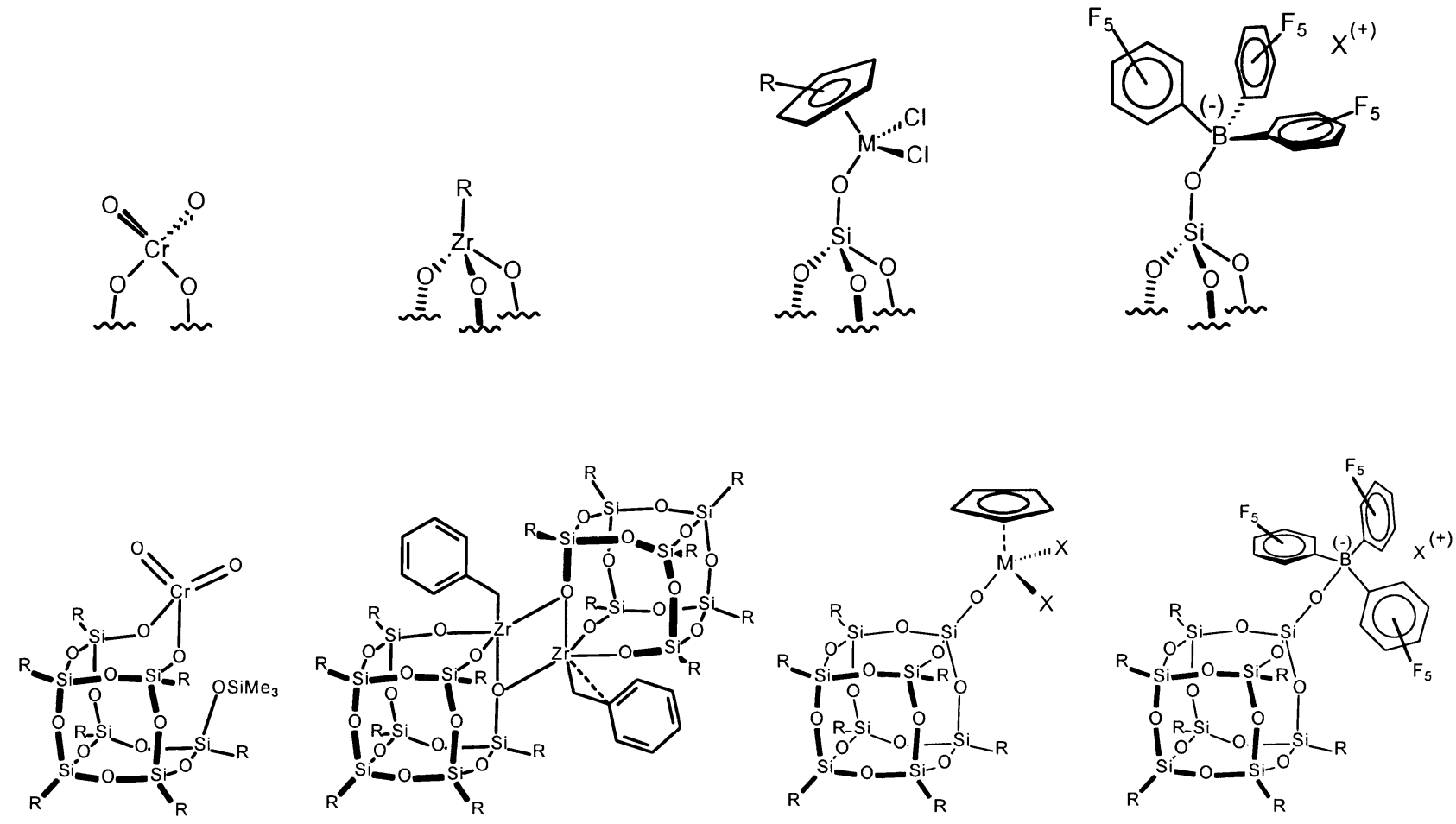

Fig. 1 Examples of silica supported species that have been modeled with metallasilsesquioxane complexes.
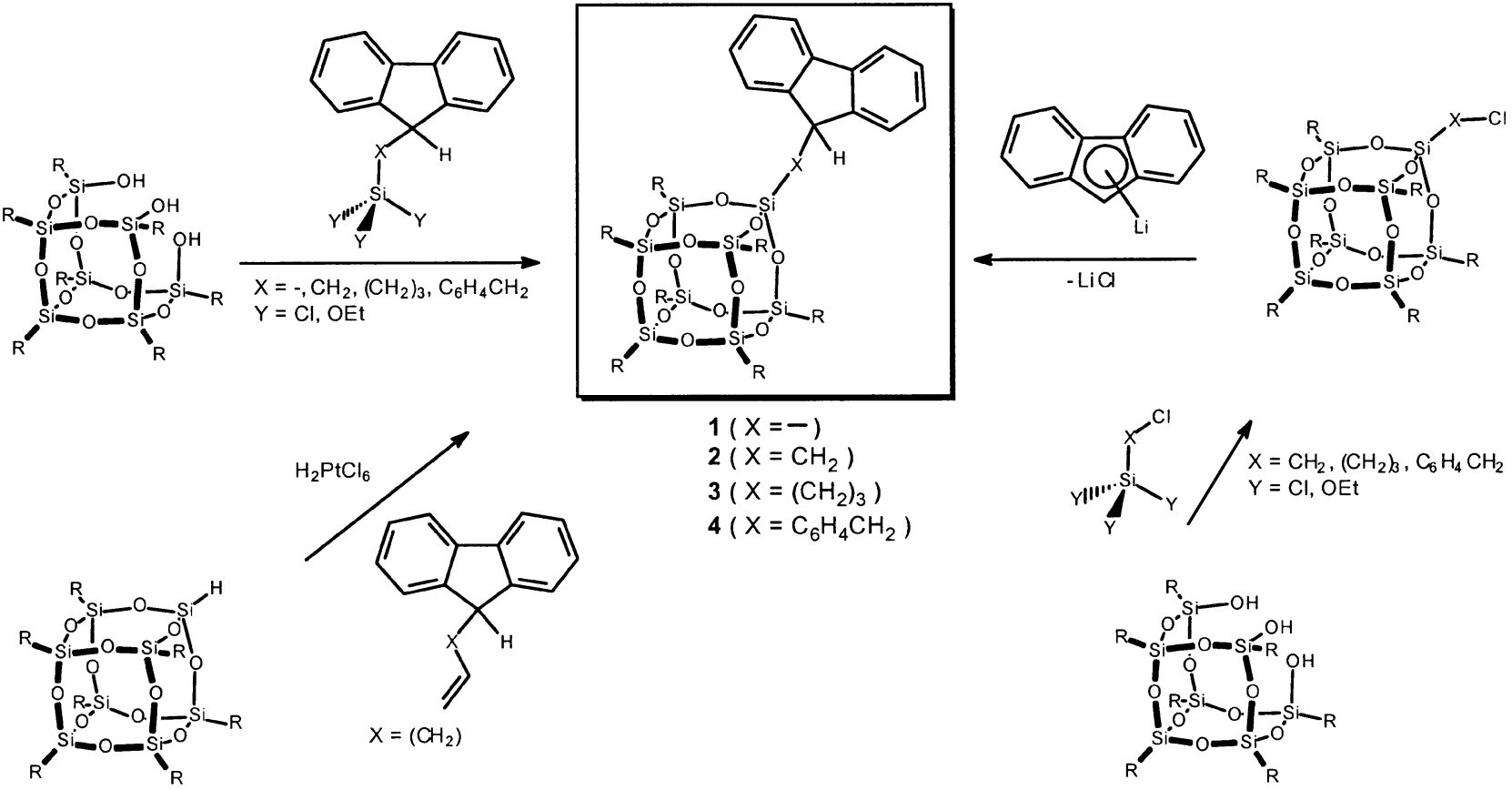

Scheme 1 Synthetic methodologies to silsesquioxane-tethered fluorenyl ligands containing different spacers.

ized substrates. ${ }^{7,17}$ Likewise, treating the trisilanol species $\left(c-\mathrm{C}_{5} \mathrm{H}_{9}\right)_{7} \mathrm{Si}_{7} \mathrm{O}_{9}(\mathrm{OH})_{3}$ with $(\mathrm{EtO})_{3} \mathrm{Si}-\mathrm{X}-9-\mathrm{Flu}(\mathrm{H})\left(\mathrm{X}=\mathrm{CH}_{2}\right.$, $\left.\left(\mathrm{CH}_{2}\right)_{3}\right)$ afforded the corner-capped silsesquioxane-substituted fluorene ligands $\left(c-\mathrm{C}_{5} \mathrm{H}_{9}\right)_{7} \mathrm{Si}_{8} \mathrm{O}_{12} \mathrm{X}-9-\mathrm{Flu}(\mathrm{H}) \quad\left(\mathrm{X}=\mathrm{CH}_{2}\right.$ (2), $\left(\mathrm{CH}_{2}\right)_{3}(3)$, Scheme 1$)$ in moderate yield $(\approx 55 \%)$. Substitution of all three ethoxy groups proved difficult, and prolonged heating was required for the reactions to go to completion. The ligands 1-4 (Scheme 1) were obtained in better yields $(\approx 80 \%)$ when $\left(c-\mathrm{C}_{5} \mathrm{H}_{9}\right)_{7} \mathrm{Si}_{7} \mathrm{O}_{9}(\mathrm{OH})_{3}$ was treated with $\mathrm{Cl}_{3} \mathrm{Si}-\mathrm{X}-9-\mathrm{Flu}(\mathrm{H})(\mathrm{X}=$ $\left.\mathrm{CH}_{2},\left(\mathrm{CH}_{2}\right)_{3}, \mathrm{C}_{6} \mathrm{H}_{4} \mathrm{CH}_{2}\right)$ in the presence of triethylamine. Unexpectedly, the silsesquioxane substituents $(\mathrm{R}=$ cyclopentyl, cyclohexyl) in $\mathrm{R}_{7} \mathrm{Si}_{7} \mathrm{O}_{9}(\mathrm{OH})_{3}$ strongly influence the reaction with $\mathrm{Cl}_{3} \mathrm{Si}-9-\mathrm{Flu}(\mathrm{H})$. For the cyclopentyl-substituted silsesquioxane, the yield was low and side products dramatically hampered purification. In contrast, the cyclohexyl-substituted silsesquioxane-fluorene ligand $\mathbf{1}$ was isolated in good yield. The ligands $2-4$ can also be prepared in two steps by first reacting $\left(c-\mathrm{C}_{5} \mathrm{H}_{9}\right)_{7} \mathrm{Si}_{7} \mathrm{O}_{9}(\mathrm{OH})_{3}$ with $(\mathrm{EtO})_{3} \mathrm{Si}-\mathrm{X}-\mathrm{Cl}$ or $\mathrm{Cl}_{3} \mathrm{Si}-\mathrm{X}-\mathrm{Cl}$ in the presence of an amine affording $\left(c-\mathrm{C}_{5} \mathrm{H}_{9}\right)_{7} \mathrm{Si}_{8} \mathrm{O}_{12} \mathrm{XCl}$, followed by reaction with fluorenyllithium (Scheme 1). The propyl spaced silsesquioxane-fluorenyl ligand $\mathbf{3}$ has also been synthesized by hydrosilylation of the cuboctameric silane $\left(c-\mathrm{C}_{5} \mathrm{H}_{9}\right)_{7} \mathrm{Si}_{8} \mathrm{O}_{12} \mathrm{H}$ with 9-allyl-fluorene (Scheme 1). Although the yield was reasonably good $(71 \%)$, purification of the sticky crude product was cumbersome.

$\mathrm{Si}-\mathrm{O}$ bond breaking by nucleophiles such as $\mathrm{BuLi}$ or $\mathrm{NaOMe}$ is a well-known reaction for silsesquioxanes and silicas. ${ }^{18}$ Therefore, the occurrence of possible side reactions during the 
deprotonation of $\mathbf{1}$ and $\mathbf{2}$ was carefully examined. First, the ligands were reacted with $\mathrm{BuLi}$ in $\mathrm{THF}$ at $0{ }^{\circ} \mathrm{C}$ and subsequently treated with trimethylsilylchloride and trimethylstannylchloride. When ligand 1 was reacted with $\mathrm{BuLi}$, instead of the characteristic red color for fluorenyl anions, a pale yellow solution was formed. Quenching with $\mathrm{Me}_{3} \mathrm{ECl}(\mathrm{E}=\mathrm{Si}, \mathrm{Sn})$ exclusively gave unidentifiable products. In 1 the sterically demanding silsesquioxane substituent is directly bonded to the fluorene, which probably hampers the deprotonation of $\mathbf{1}$ and allows nucleophile-induced $\mathrm{Si}-\mathrm{O}$ bond breaking to become competitive. Treatment of 2 with $\mathrm{BuLi}$ in THF at $0{ }^{\circ} \mathrm{C}$ afforded a cherry red colored solution, ${ }^{19}$ characteristic of a fluorenyl anion. Subsequent treatment with either trimethylsilylchloride or trimethylstannylchloride cleanly afforded the corresponding colorless silyl- and stannyl-substituted products, $\left(c-\mathrm{C}_{5} \mathrm{H}_{9}\right)_{7} \mathrm{Si}_{8}$ $\mathrm{O}_{12} \mathrm{CH}_{2}-9-\mathrm{Flu}\left(9-\mathrm{ESiMe}_{3}\right)(\mathrm{E}=\mathrm{Si}(\mathbf{5 a}), \mathrm{Sn}(\mathbf{5 b})$, Scheme 2) in high yield. This indicates that competitive $\mathrm{Si}-\mathrm{O}$ bond breaking does not occur under these conditions. In analogy to $\mathbf{2}$, ligands 3 and $\mathbf{4}$ were also readily deprotonated when treated with BuLi.

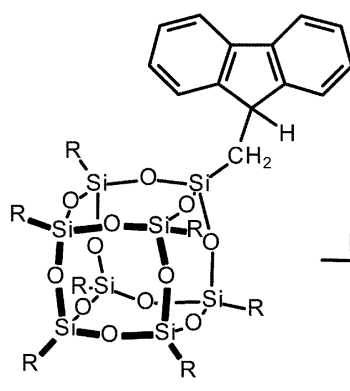

2

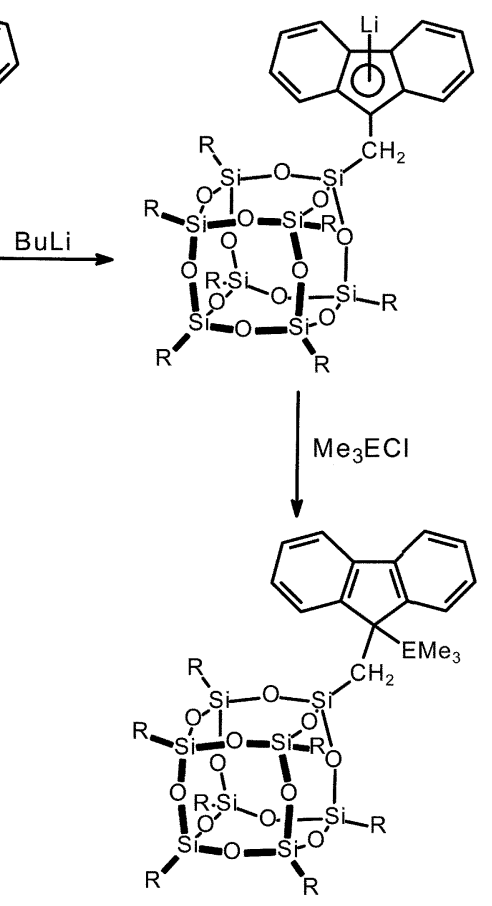

$E=S i(5 a), S n(5 b)$
Scheme 2 Deprotonation of $\mathbf{1}$ followed by reaction with $\mathrm{Me}_{3} \mathrm{ECl}$ $(\mathrm{E}=\mathrm{Si}, \mathrm{Sn})$.

The ${ }^{13} \mathrm{C}$ and ${ }^{29} \mathrm{Si}$ NMR spectra of $\mathbf{1}-\mathbf{5} \mathbf{a} / \mathbf{b}$ show the expected resonances for the $\mathrm{CH}-\mathrm{C}_{5} \mathrm{H}_{9}(1: 3: 3$ ratio $)$ and $(\equiv \mathrm{O})_{3} \mathrm{SiC}_{5} \mathrm{H}_{9}$, and $(\equiv \mathrm{O})_{3} \mathrm{SiCH}_{2}\left(1: 3: 3: 1\right.$ ratio) resonances of a $C_{3}$ symmetric silsesquioxane ligand, respectively.

The solid-state structures of $\mathbf{1}$ and $\mathbf{5 b}$ as derived from singlecrystal X-ray diffraction studies are illustrated in Fig. 2. As expected, the silsesquioxane frameworks of both ligands are very similar. In both ligands the $\mathrm{Si}-\mathrm{O}$ distances (1: 1.596(3)-

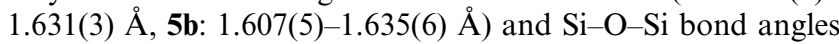
(1: $\left.143.0(2)-161.3(2)^{\circ}, \quad 5 b: 147.3(4)-152.0(4)^{\circ}\right)$ are normal within the wide range of $\mathrm{Si}-\mathrm{O}$ distances and $\mathrm{Si}-\mathrm{O}-\mathrm{Si}$ angles found for silsesquioxanes. To reduce the steric hindrance between the fluorenyl group and silsesquioxane-cyclopentyl substituents in $\mathbf{5 b}$, the Si1-C1-C90 angle is slightly opened to

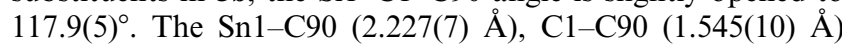
distances and $\mathrm{C} 1-\mathrm{C} 90-\mathrm{Sn} 1$ angle of $108.2(5)^{\circ}$ in $\mathbf{5 b}$ compare well with those (1.554 $\AA, 2.245 \AA$ and $109.02^{\circ}$, respectively) in 9-Me-Flu $\left(9-\mathrm{SnMe}_{3}\right){ }^{20}$

Silsesquioxanes are known to be strongly electron withdrawing substituents. ${ }^{21}$ To assess the actual electronic influence of
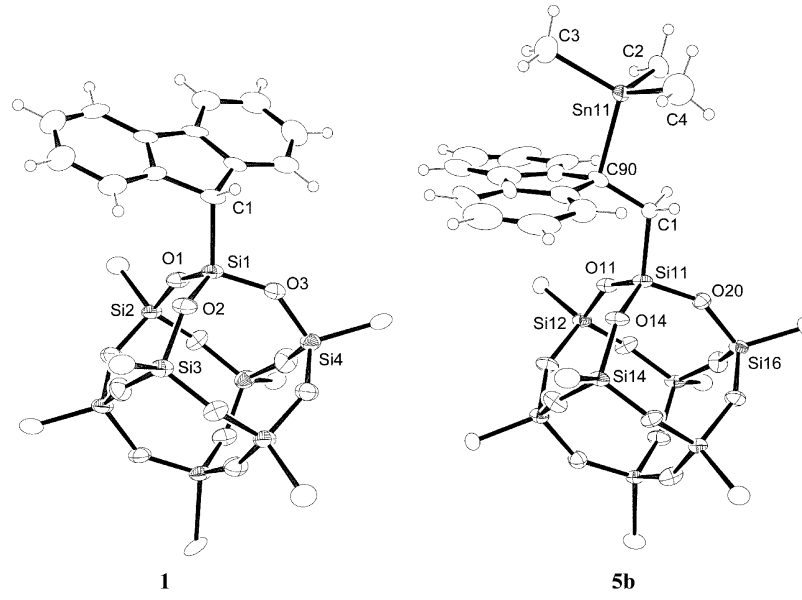

Fig. 2 Molecular structures of $\left(c-\mathrm{C}_{6} \mathrm{H}_{11}\right)_{7} \mathrm{Si}_{8} \mathrm{O}_{12} \mathrm{Flu}(\mathrm{H})$ (1) and $\left(c-\mathrm{C}_{5} \mathrm{H}_{9}\right)_{7} \mathrm{Si}_{8} \mathrm{O}_{12} \mathrm{CH}_{2}-9-\mathrm{Flu}\left(9-\mathrm{SnMe}_{3}\right)(\mathbf{5 b})$. Only the methyne carbons of the cycloalkyl groups are shown for clarity. Displacement ellipsoids are drawn at the $40 \%$ probability level. Only one of the two independent molecules of $\mathbf{5 b}$ is shown. Selected bond distances (Å) 1: Si1-O1, 1.596(3); Si1-O2, 1.617(3); Si1-O3, 1.618(3); Si1-C1, 1.863(5); Si2-O1, 1.626(3); Si3-O2, 1.631(3); Si4-O3, 1.632(3). 5b: Si11-O14, 1.616(5); Si11-O20, 1.621(6); Si11-O11, 1.614(6); Si11-C1, 1.851(7); C1-C90, 1.539(10); Sn-C90, 2.228(7). Selected angles (degrees) 1: Si1-O1-Si2, 156.9(2); Si1-O2-Si3, 144.5(2); Si1-O3-Si4, 142.8(2); C1-Si1-O1, 109.2(2); C1-Si1-O2, 108.6(2); C1-Si1-O3, 108.4(2). 5b: Sil1-O14 Si14, 149.6(4); Si11-O20-Si16, 148.1(4); Si11-O11-Si12, 148.8(4); O14-Si11-C1, 110.8(3); O20-Si11-C1, 105.6(3); O11-Si11-C1, 110.8(4); Si11-C1-C90, 118.2(5); C1-C90-Sn11, 108.5(5).

the silsesquioxane substituent in $\mathbf{2}$, a comparative acidity experiment was carried out using equimolar amounts of $\mathbf{2}$, $9-\mathrm{Me}-\mathrm{Flu}(\mathrm{H})$ and $n$-BuLi. The silsesquioxane containing fluorene 2 was found to be considerably more acidic than 9-Me$\operatorname{Flu}(\mathrm{H})\left(\Delta p \mathrm{~K}_{\mathrm{a}} \geq 1.5\right.$ by $\left.{ }^{1} \mathrm{H} \mathrm{NMR}\right)$. In spite of the methylene unit, the silsesquioxane substituent has a significant electronwithdrawing effect on the fluorene ligand and consequently on the metal center. Hence, longer isolating spacers are required to block the electronic influence of the (model) support.

\section{Silsesquioxane-tethered zirconocenes}

Initial attempts to form silsesquioxane-tethered zirconocene complexes concentrated on the reaction of the trimethylsilyl (5a) or trimethylstannyl (5b) containing fluorenes with (substituted) cyclopentadienyl zirconium trichloride. ${ }^{22}$ Although reactions were observed for all, purification of the final product proved very difficult. Deprotonation of the fluorenes (2-4) with butyllithium in THF, followed by reacting with the appropriate zirconium precursor in toluene proved to be a more successful strategy. In agreement with the earlier observed difficulty to cleanly lithiate $\mathbf{1}$, reaction of the in situ prepared fluorenyllithium salt of 1 with $\mathrm{Cp}^{\prime \prime} \mathrm{ZrCl}_{3}\left(\mathrm{Cp}^{\prime \prime}=1,3-\mathrm{C}_{5} \mathrm{H}_{3}\left(\mathrm{SiMe}_{3}\right)_{2}\right)$ did not give a well-defined product. In contrast, lithiation of $\mathbf{2 - 4}$ followed by reaction with $\mathrm{Cp} * \mathrm{ZrCl}_{3}, \mathrm{Cp}^{\prime \prime} \mathrm{ZrCl}_{3}$ and $\mathrm{ZrCl}_{4}$ afforded the corresponding zirconocene dichlorides 6-9 in moderate to good isolated yield (Scheme 3). The NMR data of the mixed zirconocenes correspond well with each other. The ${ }^{13} \mathrm{C}$ NMR chemical shifts for the fluorenyl-C(9) carbons of 6-9 $(96.72-114.32 \mathrm{ppm})$ indicate that in solution the fluorenyl moieties in these complexes adopt an $\eta^{5}$-bonding mode $\left(\eta^{5}=c a .100 \mathrm{ppm}, \eta^{3}=c a .78 \mathrm{ppm}\right.$ and $\left.\eta^{1}=c a .68 \mathrm{ppm}\right){ }^{23}$

The solid-state structures of $\mathbf{6 b}$ as derived from single-crystal $\mathrm{X}$-ray diffraction study is illustrated in Fig. 3. The structure consists of a standard metallocene in which the tetrahedrally surrounded zirconium atom is $\eta^{5}$-bonded to the cyclopentadienyl and fluorenyl ligands, while the coordination sphere is filled with two additional chlorides. The $\mathrm{Zr}-\mathrm{Cp}_{\text {centroid }}$ and $\mathrm{Zr}-\mathrm{Flu}_{\text {centroid }}$ distances in $\mathbf{6 b}(2.217 \AA, 2.269 \AA)$ are comparable to the bond distances for example found for the 

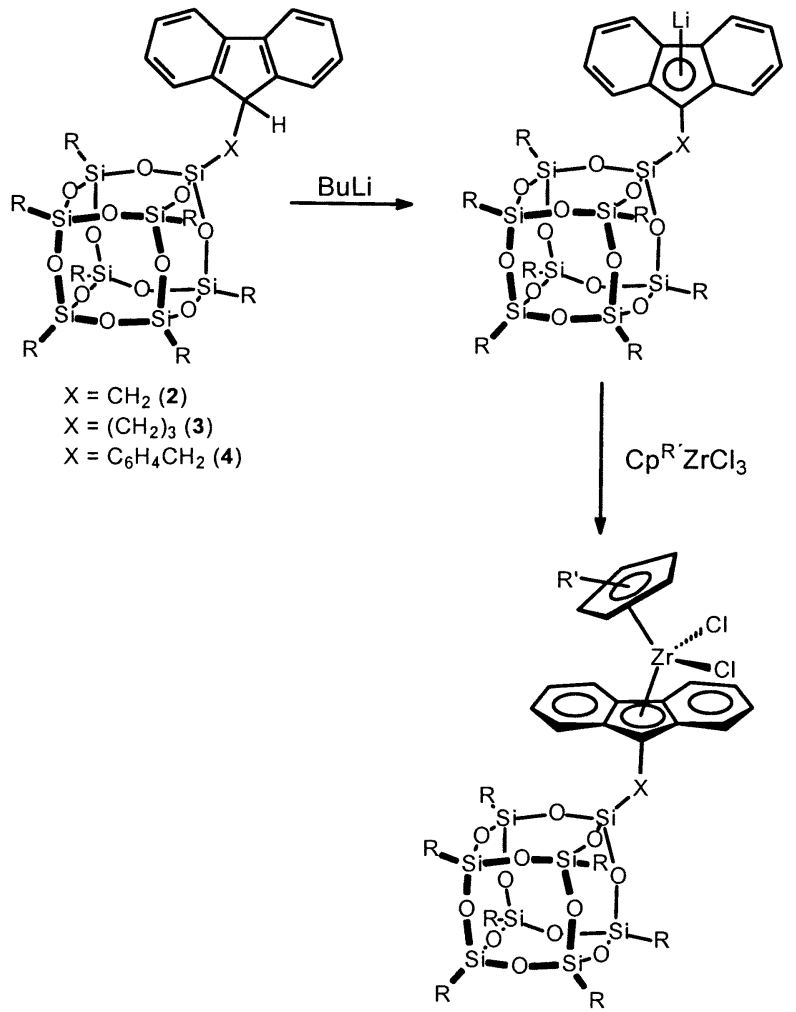

$X=C H_{2}, C p^{R^{\prime}}=C p^{*}(6 a), C p^{\prime \prime}(6 b), 2(9)$

$\mathrm{X}=\left(\mathrm{CH}_{2}\right)_{3}, \mathrm{Cp}^{\mathrm{R}^{\prime}}=\mathrm{Cp}^{*}(7)$

$\mathrm{X}=\mathrm{C}_{6} \mathrm{H}_{4} \mathrm{CH}_{2}, \mathrm{Cp}^{\mathrm{R}^{\prime}}=\mathrm{Cp}^{*}(\mathbf{8})$

Scheme 3 Synthesis of silsesquioxane containing zirconocenes.

complexes $\mathrm{Cp}^{\prime \prime}{ }_{2} \mathrm{ZrCl}_{2}(2.20 \AA),{ }^{24} \mathrm{Cp}^{*}(\mathrm{Cp}) \mathrm{ZrCl}_{2}(2.219 \AA)^{25}$ and 9-substituted-fluorenyl metallocenes, $\mathrm{Cp}[9-\mathrm{R}-\mathrm{Flu}] \mathrm{ZrCl}_{2}$ $\left(\mathrm{R}=i-\mathrm{Pr}, 2.294 \AA, \mathrm{R}=c-\mathrm{C}_{6} \mathrm{H}_{11}=2.253 \AA ; \mathrm{R}=t-\mathrm{Bu}, 2.278 \AA\right)^{23}$ and $\left[\mathrm{C}_{2} \mathrm{H}_{4}\left(\mathrm{C}_{5} \mathrm{Me}_{4}\right)(\mathrm{Flu})\right] \mathrm{ZrCl}_{2}(2.21(8) \AA) .{ }^{26} \mathrm{The} \mathrm{Cl}-\mathrm{Zr}-\mathrm{Cl}$ and the $\mathrm{Cp}^{\prime}-\mathrm{Zr}-\mathrm{Flu}$ bond angles of $\mathbf{6 b}\left(\mathrm{Cl}-\mathrm{Zr}-\mathrm{Cl}, 96.00(4)^{\circ} ; \mathrm{Cp}^{\prime \prime}-\right.$ $\left.\mathrm{Zr}-\mathrm{Flu}, 128.8(1)^{\circ}\right)$ are very similar to the corresponding bond angles for the literature complexes $\mathrm{Cp}[9-i-\mathrm{Pr}-\mathrm{Flu}] \mathrm{ZrCl}_{2}(\mathrm{Cl}-\mathrm{Zr}-$ $\mathrm{Cl}$, 97.23(5) ${ }^{\circ}$; $\left.\mathrm{Cp}-\mathrm{Zr}-\mathrm{Flu}, 129.8(5)\right), \mathrm{Cp}\left[9-c-\mathrm{C}_{6} \mathrm{H}_{11}-\mathrm{Flu}\right] \mathrm{ZrCl}_{2}$ $\left(\mathrm{Cl}-\mathrm{Zr}-\mathrm{Cl}, 96.3(1)^{\circ} ; \mathrm{Cp}-\mathrm{Zr}-\mathrm{Flu}, 129.8(2)\right)$, Cp[9-t-Bu-Flu]$\mathrm{ZrCl}_{2}\left(\mathrm{Cl}-\mathrm{Zr}-\mathrm{Cl}\right.$, 95.5(1) ${ }^{\circ}$ Cp-Zr-Flu, 129.7(2) ${ }^{23}$ and in $\mathrm{C}_{2} \mathrm{H}_{4}\left(\mathrm{C}_{5} \mathrm{Me}_{4}\right)(\mathrm{Flu}) \mathrm{ZrCl}_{2} \quad\left(\mathrm{Cl}-\mathrm{Zr}-\mathrm{Cl}, \quad 96.77(3)^{\circ}\right.$; $\mathrm{Cp}-\mathrm{Zr}-\mathrm{Flu}$ 128.2(9) $\AA$ ). ${ }^{24}$ This suggests that, although the silsesquioxane is a very large substituent, the effective steric bulk of the methylene-silsesquioxane substituent is not excessive. The average $\mathrm{Si}-\mathrm{O}$ distances (1.616(3) $\AA$ ) and $\mathrm{Si}-\mathrm{O}-\mathrm{Si}$ bond angles $\left(149.2(2)^{\circ}\right)$ are normal within the wide range of $\mathrm{Si}-\mathrm{O}$ distances and $\mathrm{Si}-\mathrm{O}-\mathrm{Si}$ angles found for silsesquioxanes.

\section{Tethering of zirconocenes containing an anchorable functionality}

The second strategy to tether homogeneous catalysts to a support consists of treating the support with a catalyst precursor containing an anchorable functionality. ${ }^{8}$ This route probably has the highest chance of forming a uniform surface metal complex. However, several side reactions can result in decomposition of the catalyst precursor. Furthermore, synthesis of such metal complexes containing a pendant anchorable, reactive functionality is often not trivial. To get better insight in the possibilities and bottlenecks of this method, we synthesized two zirconocene complexes containing an anchorable pendant functionality $\mathrm{Cp}^{\prime \prime}\left[\mathrm{FluCH}_{2} \mathrm{Si}(\mathrm{OEt}) \mathrm{Me}_{2}\right] \mathrm{ZrCl}_{2}$ (10) and $\mathrm{Cp}\left[\mathrm{C}_{5}\right.$ $\left.\mathrm{Me}_{4} \mathrm{Si}(\mathrm{OEt}) \mathrm{Me}_{2}\right] \mathrm{ZrCl}_{2}$ (11), and treated them with the silsesquioxane trisilanol. Reacting $\mathrm{Cp}^{\prime \prime}\left[\mathrm{FluCH}_{2} \mathrm{Si}(\mathrm{OEt}) \mathrm{Me}_{2}\right] \mathrm{ZrCl}_{2}$ with $\left(c-\mathrm{C}_{5} \mathrm{H}_{9}\right)_{7} \mathrm{Si}_{7} \mathrm{O}_{9}(\mathrm{OH})_{3}$ resulted in loss of the fluorenyl ligand and both of the chlorides, affording the corner-capped zirconium silsesquioxane, $\left[\left(c-\mathrm{C}_{5} \mathrm{H}_{9}\right)_{7} \mathrm{Si}_{7} \mathrm{O}_{12}\right] \mathrm{ZrCp}^{\prime \prime}$ (Scheme 4). ${ }^{14}$

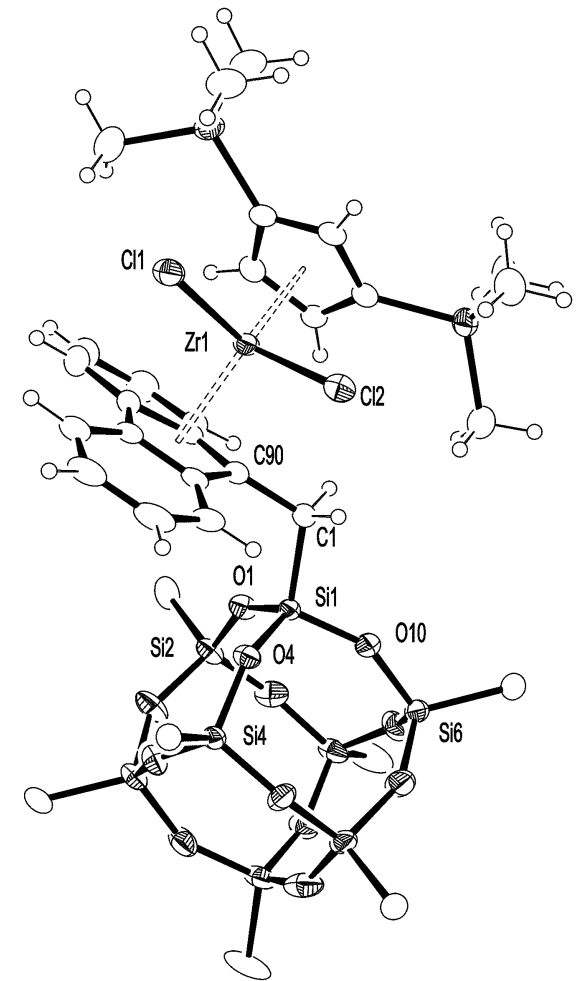

Fig. 3 Molecular structures of $\mathrm{Cp}^{\prime \prime}\left[\left(c-\mathrm{C}_{5} \mathrm{H}_{9}\right)_{7} \mathrm{Si}_{8} \mathrm{O}_{12} \mathrm{CH}_{2} \mathrm{Flu}\right] \mathrm{ZrCl}_{2}$ (6b). Only the methyne carbons of the cyclopentyl groups are shown for clarity. Displacement ellipsoids are drawn at the $40 \%$ probability level. Selected bond distances (A): Zr1-Cl1, 2.4262(11); Zr1-Cl2, 2.4288(12); $\mathrm{Zr1-C}$ pentroid $_{\text {, 2.217; Zr1-Flu }}$ centroid, 2.269 ; C1-C90, 1.508(5); Si1-C1, 1.841(4), Si1-O1, 1.615(3); Si2-O1, 1.626(3); O- $\mathrm{Si}_{\mathrm{av}}, 1.616(3)$. Selected angles (degrees): $\mathrm{Cp}^{\prime \prime}{ }_{\text {centroid }}-\mathrm{Zr} 1-\mathrm{Flu}_{\text {centroid }}, 128.8(1) ; \mathrm{Cl1}-\mathrm{Zr} 1-\mathrm{Cl} 2$, 96.00(4); Si1-C1-C90, 116.4(3); SilO1-Si4, 146.84(19); O1-Si1-C1, 109.55(17); O4-Si1-C1, 109.23(17); O10-Si1-C1, 108.15(15); Si-O$\mathrm{Si}_{\mathrm{av}}, 149.2(2)$.

Clearly, the pendant silylether functionality is protonated considerably slower than both the chlorides and the fluorenyl ligand. Protonolysis of chloride- and cyclopentadienyl ligands in group 4 metal systems by silsesquioxane silanols has been reported before. ${ }^{27}$ Generally, reactions of the chloride substituents of the metallocene precursors are amine assisted. In our case the chlorides are readily displaced even without an amine, which is probably caused by the formation of the favorable corner-capped structure $\left[\left(c-\mathrm{C}_{5} \mathrm{H}_{9}\right)_{7} \mathrm{Si}_{7} \mathrm{O}_{12}\right] \mathrm{ZrCp}^{\prime \prime}$.

To favor the reactivity of the pendant silylether functionality, a zirconocene with more protonolysis-stable cyclopentadienyls compared to the fluorenyl ligand in 10, $\mathrm{Cp}\left[\mathrm{Me}_{2}(\mathrm{EtO}) \mathrm{SiC}_{5^{-}}\right.$ $\left.\mathrm{Me}_{4}\right] \mathrm{ZrCl}_{2}$ (11), was applied. When $\left(c-\mathrm{C}_{5} \mathrm{H}_{9}\right)_{7} \mathrm{Si}_{7} \mathrm{O}_{9}(\mathrm{OH})_{3}$ was reacted with 11 (Scheme 5), a positive chlorine test on the volatiles proved that the chloride substituents were readily eliminated while the SiOEt functionality remained intact (based on NMR). Prolonged heating to $80^{\circ} \mathrm{C}$ (toluene, $24 \mathrm{~h}$ ) was required to activate the SiOEt bond and to form ethanol (based on NMR and GC). The NMR $\left({ }^{1} \mathrm{H},{ }^{13} \mathrm{C},{ }^{29} \mathrm{Si}\right)$ spectra were very complicated, probably as the result of the presence of several oligomeric structures of $\left[\left(c-\mathrm{C}_{5} \mathrm{H}_{9}\right)_{7} \mathrm{Si}_{7} \mathrm{O}_{9}\left(\mathrm{O}_{2} \mathrm{ZrCp}\right)\left(\mathrm{C}_{5} \mathrm{Me}_{4^{-}}\right.\right.$ $\left.\left.\mathrm{SiMe}_{2} \mathrm{O}-\right)\right]_{n}$. Clearly, the chloride substituents on zirconium are still more reactive than the silyl-ether functionality. Hence, introducing less reactive substituents to zirconium before tethering the zirconocene onto a support is probably the best strategy to ensure a selective tethering reaction.

\section{Olefin polymerization}

Olefin polymerization experiments have been carried out using the homogenous silsesquioxane-substituted zirconocene dichlorides $(\mathbf{6} \mathbf{a} / \mathbf{b}-\mathbf{9})$. When activated with MAO, all complexes generated active single site ethylene polymerization catalysts. 
Table 1 Ethylene polymerization results ${ }^{a}$

\begin{tabular}{|c|c|c|c|c|c|}
\hline Compound & Time/min & Yield/g & Activity/g $(\mathrm{mmol}[\mathrm{Zr}] \mathrm{h})^{-1}$ & $\mathrm{Mw} / \mathrm{g} \mathrm{mol}^{-1}$ & $\mathrm{Mw} / \mathrm{Mn}$ \\
\hline $\mathrm{Cp}^{*}[$ FluMe $] \mathrm{ZrCl}_{2}$ & 5 & 9.44 & 5664 & 156,000 & 2.5 \\
\hline $6 a$ & 5 & 3.91 & 2346 & 367,000 & 3.5 \\
\hline 7 & 5 & 4.66 & 2796 & 173,000 & 3.1 \\
\hline 8 & 5 & 4.07 & 2442 & 279,000 & 3.4 \\
\hline $6 \mathbf{b}$ & 10 & 6.21 & 3860 & 409,000 & 4.9 \\
\hline $\mathrm{Cp}^{\prime \prime}[$ FluMe $] \mathrm{ZrCl}_{2}$ & 10 & 8.34 & 5554 & 122,000 & 2.9 \\
\hline 9 & 10 & 4.12 & 2570 & 7,000 & 2.2 \\
\hline$[\text { FluMe }]_{2} \mathrm{ZrCl}_{2}$ & 10 & 6.28 & 3920 & 12,000 & 2.5 \\
\hline
\end{tabular}

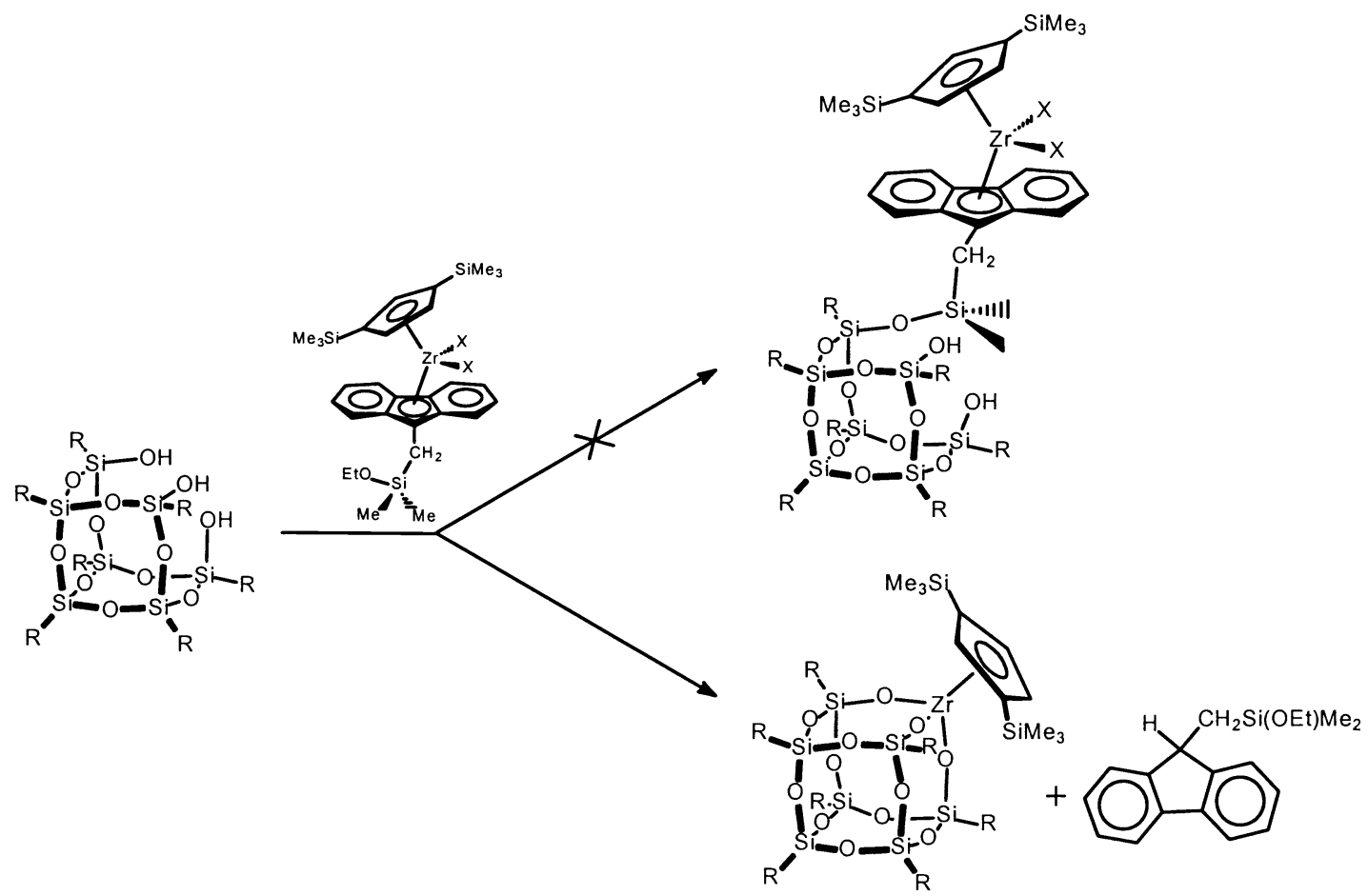

Scheme 4 Protonolysis of silsesquioxane containing zirconocenes.

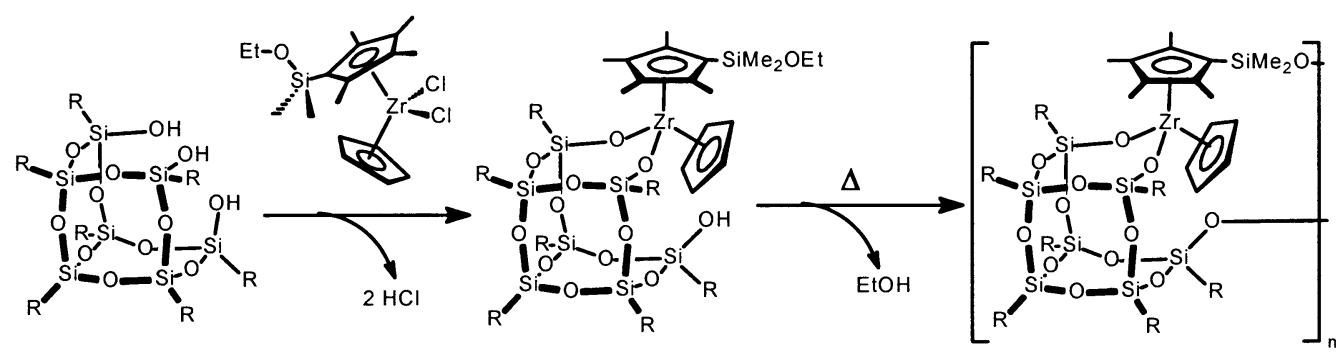

Scheme 5 Competitive tethering and grafting of zirconocenes

The polymerization activities of 6-9 are somewhat lower than of the corresponding non-silsesquioxane complexes $\mathrm{Cp}^{*}[9-\mathrm{Me}-\mathrm{Flu}] \mathrm{ZrCl}_{2}, \mathrm{Cp}^{\prime \prime}[9-\mathrm{Me}-\mathrm{Flu}] \mathrm{ZrCl}_{2}$ and $[9-\mathrm{Me}-\mathrm{Flu}]_{2}-$ $\mathrm{ZrCl}_{2}$ (Table 1), respectively. Alt and coworkers found that electron withdrawing substituents in the 9-position of the fluorenyl ligand in $\mathrm{Cp}[9-\mathrm{R}-\mathrm{Flu}] \mathrm{ZrCl}_{2}$ give rise to lower activities than electron donating ones, while steric effects influenced the activity much less. ${ }^{23}$ This argument might explain the lower activity of $6 \mathbf{a} / \mathbf{b}, 8$ and 9 but not that of 7 , which contains a truly isolating spacer between the fluorene and the silsesquioxane.

\section{Discussion}

Three general routes have been applied to tether cyclopentadienes to surface supports. They consist of $(i)$ grafting of a silylchloride or silylether functionalized cyclopentadiene, (ii) salt elimination reaction of a cyclopentadienyl alkali-metal salt with an alkylchloride group previously tethered onto the surface by method $i$ or e.g. sol-gel synthesis and (iii) hydrosilylation of an olefin substituted cyclopentadienyl (Scheme 1). Once the cyclopentadienyl ligand is attached to the silsesquioxane it can be deprotonated and treated with the metal precursor (Scheme 3). The most successful route to silsesquioxane-tethered fluorenes proved to be the reaction of $\left(c-\mathrm{C}_{5} \mathrm{H}_{9}\right)_{7} \mathrm{Si}_{7} \mathrm{O}_{9}(\mathrm{OH})_{3}$ with $\mathrm{Cl}_{3} \mathrm{Si}-\mathrm{X}-9-\mathrm{Flu}(\mathrm{H})$ (or $\mathrm{Cl}_{3} \mathrm{SiXCl}$ followed by salt metathesis with FluLi) in the presence of an amine. The alcohol elimination reaction of $\left(c-\mathrm{C}_{5} \mathrm{H}_{9}\right)_{7} \mathrm{Si}_{7} \mathrm{O}_{9^{-}}$ $(\mathrm{OH})_{3}$ with $(\mathrm{RO})_{3} \mathrm{Si}-\mathrm{X}-9-\mathrm{Flu}(\mathrm{H})$ (or $(\mathrm{RO})_{3} \mathrm{SiXCl}$, followed by salt metathesis with FluLi) is considerably slower, as heating is required for the reaction to go to completion. When the salt metathesis route would be applied on a solid support, the necessity to remove the ammonium salt formed by the former 
method might be a disadvantage. Furthermore, although crucial for obtaining clean silsesquioxane-based products, substitution of all three OR groups of the $(\mathrm{RO})_{3} \mathrm{Si}-\mathrm{X}-9-\mathrm{Flu}(\mathrm{H})$ ligand is probably not necessary to tightly anchor the ligand to a silica support. Hydrosilylation between $\left(c-\mathrm{C}_{5} \mathrm{H}_{9}\right)_{7} \mathrm{Si}_{8} \mathrm{O}_{12} \mathrm{H}$ and 9-allyl-fluorene proved to be a useful reaction to the desired product. However, hydrosilylation of ancillary ligands or catalysts onto silica supports requires that the supports are covered with $\mathrm{Si}-\mathrm{H}$ moieties. The presence of silane functionalities during polymerization is not always desirable since silanes are known to be effective chain-transfer agents. ${ }^{28}$ The selectivity of both anchoring the fluorene ligand to the silsesquioxane support and introduction of the zirconium is moderate. For silsesquioxanes this synthetic strategy is convenient only because the silsesquioxane-bonded ancillary ligand and the metal complexes thereof can be purified reasonably easy. More importantly, there are no adjacent silanol functionalities that can interfere with the intended reactions. Using this multistep approach to form silica-tethered zirconocene systems is therefore likely to result in more than one type of surface metal sites. Immobilization of catalyst precursors containing an anchorable functionality has a higher chance of forming a single-site supported catalyst. However, even with this route side reactions such as protonation of the ancillary ligands and competitive grafting of the metal center to the support are hard to avoid. Nevertheless, as long as the cyclopentadienyl ligands remain attached to the zirconium competitive grafting of zirconium to the support does not necessary prevent the formation of a uniform silica-tethered metallocene catalyst. As was reported earlier, silsesquioxanegrafted zirconocenes form active olefin polymerization catalysts after activation with $\mathrm{MAO}$, as the latter effectively splits $\mathrm{Zr}-\mathrm{OSi}$ bonds. ${ }^{14} \mathrm{Hence}$, complexes of the type $\left[\left(c-\mathrm{C}_{5} \mathrm{H}_{9}\right)_{7^{-}}\right.$ $\left.\mathrm{Si}_{7} \mathrm{O}_{9}\left(\mathrm{O}_{2} \mathrm{ZrCp}\right)\left(\mathrm{C}_{5} \mathrm{Me}_{4} \mathrm{SiMe}_{2} \mathrm{O}-\right)\right]_{n}$ can be activated in the same way; the metal-siloxy bonds will be cleaved by the MAO, while the metallocene remains attached to the surface by the tethered cyclopentadienyl group (Scheme 5).

While a methylene tethering-unit is large enough to effectively avoid close contact between the metal site and the silsesquioxane model support, it seems to be insufficient to block the strong electron withdrawing effect of the silsesquioxane moiety. The rigid benzyl spacer in $\mathbf{8}$ effectively forces the zirconocene away from the model support, but still allows inductive electronic influence from the silsesquioxane. To truly block the electron withdrawing effect of the silsesquioxane fragment, an insulating spacer unit such as the propylene bridge in 7 is required. Unexpectedly, compound 7 also shows a lower activity than $\mathrm{Cp}[9-\mathrm{Me}-\mathrm{Flu}] \mathrm{ZrCl}_{2}$ suggesting that the catalytic activity of these species is not affected by electronic effects alone. Probably the steric hindrance of the adjacent silsesquioxane fragment still affects the catalytic behavior of these complexes somehow.

\section{Concluding remarks}

These results demonstrate that using silsesquioxane model supports to determine the most promising reaction methodology for tethering ancillary ligands to silicas, proved to be very beneficial. Although no ideal tethering strategy was found, this study clearly demonstrated various difficulties than can be encountered when oxophilic and hydrolysis-sensitive metallocenes are being tethered onto oxidic supports. For these silsesquioxane systems, the most successful route to silsesquioxane-tethered zirconocene species proved to be the sequential synthesis of first the silsesquioxane-fluorene ligand followed by introduction of zirconium. Although, the selectivity of both anchoring the fluorene ligand to the silsesquioxane support and introduction of the zirconium is moderate, this synthetic strategy is convenient only because the silsesquioxane-bonded ancillary ligand and the metal complexes thereof can be purified.
More importantly, there are no adjacent silanol functionalities that can interfere with the intended reactions. Although tethering of catalysts containing an anchorable functionality was expected to have the highest chance of yielding uniform surface metal complexes, even for these well-defined silsesquioxane model supports complex mixtures were obtained. Competitive grafting of the zirconium onto the silsesquioxane proved to be the main problem.

\section{Experimental}

\section{General comments}

All manipulations were performed under an argon atmosphere using glove box (Braun MB-150 GI) and Schlenk techniques. Solvents were distilled from $\mathrm{Na}$ (toluene), $\mathrm{K}$ (THF), $\mathrm{Na} / \mathrm{K}$ alloy (hexanes), $\mathrm{Na}$ /benzophenone $\left(\mathrm{Et}_{2} \mathrm{O}\right)$ or $\mathrm{CaH}_{2}\left(\mathrm{CH}_{2} \mathrm{Cl}_{2}\right)$, stored under argon and freeze-thaw degassed twice before use. NMR solvents were dried over $\mathrm{Na} / \mathrm{K}$ alloy (benzene- $\mathrm{d}_{6}$ ) or $4 \AA$ molecular sieves $\left(\mathrm{CDCl}_{3}\right)$. NMR spectra were recorded on Varian Mercury $400\left({ }^{1} \mathrm{H} 400 \mathrm{MHz},{ }^{13} \mathrm{C}, 100.5 \mathrm{MHz}\right)$ and Varian Indigo $500\left({ }^{29} \mathrm{Si}, 100 \mathrm{MHz}\right)$ spectrometers. Chemical shifts are reported in ppm and referenced to residual solvent resonance $\left({ }^{1} \mathrm{H},{ }^{13} \mathrm{C} \mathrm{NMR}\right)$ or internal TMS $\left({ }^{29} \mathrm{Si} \mathrm{NMR}\right)$. GC's were recorded on a Carlo Erba GC 6000 chromatograph (column: DB-1, 30M). Elemental analyses were carried out at the University of Groningen (The Netherlands) and H. Kolbe Mikroanalytisches laboratorium Mülheim (Germany). $\mathrm{V}_{2} \mathrm{O}_{5}$ was added to improve combustion and to reduce the oftenobserved formation of silicon carbide. $\left(c-\mathrm{C}_{5} \mathrm{H}_{9}\right) \mathrm{Si}_{7} \mathrm{O}_{9}(\mathrm{OH})_{3},{ }^{11}$ $\left(c-\mathrm{C}_{5} \mathrm{H}_{9}\right)_{7} \mathrm{Si}_{8} \mathrm{O}_{12}(\mathrm{OH}),{ }^{14} \mathrm{Flu}(\mathrm{H}) \mathrm{SiCl}_{3}{ }^{29}$ and $\mathrm{Cp}^{\prime \prime} \mathrm{ZrCl}_{3}\left(\mathrm{Cp}^{\prime \prime}=1,3-\right.$ $\left.\mathrm{C}_{5} \mathrm{H}_{3}\left(\mathrm{SiMe}_{3}\right)_{2}\right)^{30}$ were prepared by the following literature procedures. $\mathrm{Cp}^{*} \mathrm{ZrCl}_{3}\left(\mathrm{Cp}^{*}=\mathrm{C}_{5} \mathrm{Me}_{5}\right.$; DSM Research B.V.), trichlorosilanes (Gelest), $\mathrm{C}_{5} \mathrm{Me}_{4}(\mathrm{H}) \mathrm{SiMe}_{2} \mathrm{Cl}$ (Aldrich) and methylaluminoxane (Witco) were used as purchased. Zirconium tetrachloride (Lancaster) was freshly sublimed (twice) prior to use. Experimental details for the synthesis of $\mathbf{4 , 5 b}$ and 6b and NMR data for all compounds, as well as crystal data and experimental details on the crystal structure determinations of $\mathbf{1 , 5 b}$ and $\mathbf{6 b}$ can be found in the Electronic supplementary information (ESI) $\dagger$

CCDC reference numbers 201605 (6b), 201606 (5b) and 201607 (1)

See http://www.rsc.org/suppdata/dt/b3/b300698k/ for crystallographic data in CIF or other electronic format.

$\left(c-\mathrm{C}_{6} \mathrm{H}_{11}\right)_{7} \mathrm{Si}_{8} \mathrm{O}_{12}-\mathbf{9}-\mathrm{Flu}(\mathrm{H})$ (1). To a stirred solution of $\left(c-\mathrm{C}_{6} \mathrm{H}_{11}\right)_{7} \mathrm{Si}_{7}(\mathrm{OH})_{3}(1.12 \mathrm{~g}, 1.2 \mathrm{mmol})$ in THF was added 9- $\mathrm{C}_{13} \mathrm{H}_{9} \mathrm{SiCl}_{3}(0.35 \mathrm{~g}, 1.2 \mathrm{mmol})$ at room temperature. Triethylamine $(0.5 \mathrm{~mL}, 3.6 \mathrm{mmol})$ was then added dropwise to the solution, forming a white suspension. The mixture was stirred for $16 \mathrm{~h}$ and then filtered to remove $\mathrm{NEt}_{3}(\mathrm{H}) \mathrm{Cl}$. The $\mathrm{NEt}_{3}(\mathrm{H}) \mathrm{Cl}$ was washed twice with $10 \mathrm{~mL}$ of THF, and the filtrate was evaporated. The resultant foam was then extracted with hot hexane $(\mathrm{ca} .40 \mathrm{~mL})$ and filtered to remove the last traces of $\mathrm{NEt}_{3}(\mathrm{H}) \mathrm{Cl}$. The solution was concentrated and allowed to cool and slowly evaporate, affording complex $\mathbf{1}$ as clear crystalline solid (1.14 g, $1.0 \mathrm{mmol}, 80 \%$ ). (Found: C, 56.56; H, 7.77. $\mathrm{C}_{55} \mathrm{H}_{90} \mathrm{O}_{12} \mathrm{Si}_{8}$ requires $\mathrm{C}, 56.23 ; \mathrm{H}, 7.81 \%$ ).

(c- $\left.\mathbf{C}_{5} \mathbf{H}_{9}\right)_{7} \mathbf{S i}_{8} \mathbf{O}_{12} \mathbf{C H}_{2}-\mathbf{9 - F l u ( H ) ~ ( 2 ) . ~ M e t h o d ~ I : ~ 9 - t r i s e t h o x y s i l - ~}$ ylmethyl-fluorene $(1.1 \mathrm{~g}, 3.2 \mathrm{mmol})$ was added to a suspension of $\left(c-\mathrm{C}_{5} \mathrm{H}_{9}\right)_{7} \mathrm{Si}_{7} \mathrm{O}_{9}(\mathrm{OH})_{3}(2.8 \mathrm{~g}, 3.2 \mathrm{mmol})$ in toluene $(100 \mathrm{~mL})$. A reflux condenser was fitted and the mixture was heated to reflux, at which point the reaction mixture became clear and slightly yellow in color. Heating was continued for a further 6 days, volatiles were then removed in vacuo leaving a waxy solid residue. This residue was taken up in hot hexane $(40 \mathrm{~mL})$ and then pumped to dryness. This process was repeated a further two times to leave a fine off white precipitate, which when 
washed with acetone $(20 \mathrm{~mL})$ and dried afforded compound 2 as a free flowing white solid $(2.0 \mathrm{~g}, 1.9 \mathrm{mmol}, 59 \%)$. Method II: (a) To a stirred solution of $\left(c-\mathrm{C}_{5} \mathrm{H}_{9}\right)_{7} \mathrm{Si}_{7} \mathrm{O}_{9}(\mathrm{OH})_{3}(1.5 \mathrm{~g}$, $1.7 \mathrm{mmol})$ in THF $(100 \mathrm{~mL})$ was added $\mathrm{ClCH}_{2} \mathrm{SiCl}_{3}(0.32 \mathrm{~g}$, $1.7 \mathrm{mmol})$ at room temperature. Triethylamine $(0.75 \mathrm{~mL}$, $5.4 \mathrm{mmol}$ ) was then added dropwise to the resultant solution forming a white suspension. The mixture was stirred for $16 \mathrm{~h}$, filtered to remove $\mathrm{Et}_{3} \mathrm{~N}(\mathrm{H}) \mathrm{Cl}$ and evaporated. The resultant solid was then extracted with hot hexane and filtered to remove the last traces of $\mathrm{Et}_{3} \mathrm{~N}(\mathrm{H}) \mathrm{Cl}$. The filtrate was concentrated and allowed to cool affording $\left(c-\mathrm{C}_{5} \mathrm{H}_{9}\right)_{7} \mathrm{Si}_{8} \mathrm{O}_{12} \mathrm{CH}_{2} \mathrm{Cl}$ as a crystalline solid $(1.25 \mathrm{~g}, 1.32 \mathrm{mmol}, 78 \%)$. ${ }^{1} \mathrm{H}$ NMR $\left(\mathrm{CDCl}_{3}, \delta\right): 2.78(\mathrm{~s}$ $\left.2 \mathrm{H},(\equiv \mathrm{O})_{3} \mathrm{SiCH}_{2} \mathrm{Cl}\right), 1.78\left(\mathrm{~m}, 14 \mathrm{H}, \mathrm{CH}_{2}-\mathrm{C}_{5} \mathrm{H}_{9}\right), 1.55(\mathrm{~m}, 42 \mathrm{H}$, $\left.\mathrm{CH}_{2}-\mathrm{C}_{5} \mathrm{H}_{9}\right), 1.04\left(\mathrm{~m}, \mathrm{CH}-\mathrm{C}_{5} \mathrm{H}_{9}\right) .{ }^{13} \mathrm{C}\left\{{ }^{1} \mathrm{H}\right\}\left(\mathrm{CDCl}_{3}, \delta\right): 27.26$, 27.24, 27.00, 26.95 (s, $\mathrm{CH}_{2}-\mathrm{C}_{5} \mathrm{H}_{9}$ ), 24.45 (s, $(\equiv \mathrm{O})_{3} \mathrm{SiCH}_{2} \mathrm{Cl}$ ), 22.19, 22.16, 22.03 (s, $\left.C \mathrm{H}-\mathrm{C}_{5} \mathrm{H}_{9}, 1: 3: 3\right) .{ }^{29} \mathrm{Si} \mathrm{NMR}\left(\mathrm{CDCl}_{3}, \delta\right)$ $-65.83,-66.41,-77.01(3: 4: 1)$. (b) At $0{ }^{\circ} \mathrm{C}, n$-BuL $(0.48 \mathrm{~mL}, 2.5 \mathrm{M}$ in hexanes, $1.2 \mathrm{mmol})$ was added to a stirred solution of fluorene $(0.19 \mathrm{~g}, 1.2 \mathrm{mmol})$ in THF $(30 \mathrm{~mL})$. After the mixture was stirred for $0.5 \mathrm{~h}$ at room temperature, solid $\left(c-\mathrm{C}_{5} \mathrm{H}_{9}\right)_{7} \mathrm{Si}_{8} \mathrm{O}_{12} \mathrm{CH}_{2} \mathrm{Cl}(1.0 \mathrm{~g}, 1.1 \mathrm{mmol})$ was added and stirring was continued for a further $16 \mathrm{~h}$. The solution was then treated with EtOH to neutralize the excess fluorenyl lithium. Volatiles were removed in vacuo yielding a sticky white solid. The solid was extracted with hexanes and evaporation of the volatiles affording a white powder. Subsequent washing with acetone yielded 2 as a white free flowing powder $(0.97 \mathrm{~g}, 0.9 \mathrm{mmol}$, 82\%). (Found: C, 54.50; $\mathrm{H}, 6.91 . \mathrm{C}_{49} \mathrm{H}_{74} \mathrm{O}_{12} \mathrm{Si}_{8}$ requires C, 54.17; $\mathrm{H}, 7.09 \%)$.

$\left(c-\mathbf{C}_{5} \mathbf{H}_{9}\right)_{7} \mathrm{Si}_{8} \mathbf{O}_{12}\left(\mathbf{C H}_{2}\right)_{3} \mathbf{F l u}(\mathbf{H})$ (3). Method I: (a) $\left(c-\mathrm{C}_{5} \mathrm{H}_{9}\right)_{7} \mathrm{Si}_{8}-$ $\mathrm{O}_{12}\left(\mathrm{CH}_{2}\right)_{3} \mathrm{Cl}$ was prepared in a similar way as $\left(c-\mathrm{C}_{5} \mathrm{H}_{9}\right)_{7} \mathrm{Si}_{8} \mathrm{O}_{12^{-}}$ $\mathrm{CH}_{2} \mathrm{Cl}$, starting from $\left(c-\mathrm{C}_{5} \mathrm{H}_{9}\right)_{7} \mathrm{Si}_{7} \mathrm{O}_{9}(\mathrm{OH})_{3}(6.32 \mathrm{~g}$. $7.2 \mathrm{mmol})$ and $\mathrm{Cl}_{3} \mathrm{Si}\left(\mathrm{CH}_{2}\right)_{3} \mathrm{Cl}(1.53 \mathrm{~g}, 7.2 \mathrm{mmol})$ and was isolated as a white powder $(5.77 \mathrm{~g}, 5.9 \mathrm{mmol}, 82 \%)$. (b) $\left(c-\mathrm{C}_{5} \mathrm{H}_{9}\right)_{7} \mathrm{Si}_{8} \mathrm{O}_{12^{-}}$ $\left(\mathrm{CH}_{2}\right)_{3} \mathrm{Flu}(\mathrm{H})(3)$ was prepared in a similar way as $\mathbf{2}$, starting from $\left(c-\mathrm{C}_{5} \mathrm{H}_{9}\right)_{7} \mathrm{Si}_{8} \mathrm{O}_{12}\left(\mathrm{CH}_{2}\right)_{3} \mathrm{Cl}(3.12 \mathrm{~g}, 3.2 \mathrm{mmol})$ and FluLi (prepared from fluorene $(1.60 \mathrm{~g}, 9.6 \mathrm{mmol})$ and $n$-BuL $(3.85 \mathrm{~mL}, 2.5 \mathrm{M}, 9.6 \mathrm{mmol})$ and was isolated as a white powder (1.88 g, $1.7 \mathrm{mmol}, 53 \%)$. Method II: To a toluene solution $(60 \mathrm{~mL})$ of $\left(c-\mathrm{C}_{5} \mathrm{H}_{9}\right)_{7} \mathrm{Si}_{8} \mathrm{O}_{12} \mathrm{H}(1.24 \mathrm{~g}, 1.4 \mathrm{mmol})$ and $\left(\mathrm{H}_{2} \mathrm{C}=\right.$ $\left.\mathrm{CHCH}_{2}\right)-9-\mathrm{Flu}(\mathrm{H})(1.04 \mathrm{~g}, 5 \mathrm{mmol})$ a catalytic amount of $\mathrm{H}_{2} \mathrm{PtCl}_{4}$ was added and the resultant solution heated to reflux. Heating was continued for a further 4 days after which time the volatiles were removed. The sticky residue that remained was stripped once with heptanes $(40 \mathrm{ml})$ followed by hexanes $(2 \times$ $50 \mathrm{~mL}$ ). Washing several times with acetone afforded 3 as white free flowing solid $(1.10 \mathrm{~g}, 1.0 \mathrm{mmol}, 71 \%)$ free of $\left(\mathrm{H}_{2} \mathrm{C}=\right.$ $\left.\mathrm{CHCH}_{2}\right)-9-\mathrm{Flu}(\mathrm{H})$. Method III: (a) $\left(\mathrm{H}_{2} \mathrm{C}=\mathrm{CHCH}_{2}\right)-9-\mathrm{Flu}(\mathrm{H})$ $(6.12 \mathrm{~g}, 29 \mathrm{mmol})$ was added to a toluene solution $(10 \mathrm{~mL})$ of trichlorosilane $(6.0 \mathrm{~mL}, 120 \mathrm{mmol})$. A catalytic amount of $\mathrm{H}_{2} \mathrm{PtCl}_{4}$ was added and the reaction heated to reflux. Aliquots were taken at regular intervals, the solvent was removed from each aliquot and the residue was analyzed by ${ }^{1} \mathrm{H}$ NMR. Heating was continued until all $\left(\mathrm{H}_{2} \mathrm{C}=\mathrm{CHCH}_{2}\right)-9-\mathrm{Flu}(\mathrm{H})$ was consumed (4-5 days). On completion, all volatiles were removed in vacuo and the residue distilled under high vacuum to afford $\left(\mathrm{Cl}_{3} \mathrm{Si}\left(\mathrm{CH}_{2}\right)_{3}\right)-9-\mathrm{Flu}(\mathrm{H})(8.5 \mathrm{~g}, 25 \mathrm{mmol}, 86 \%)$ as a viscous pale yellow oil. (b) To a stirred solution of $\left(\mathrm{Cl}_{3} \mathrm{Si}\left(\mathrm{CH}_{2}\right)_{3}\right)-9$-Flu(H) $(0.97 \mathrm{~g}, 2.8 \mathrm{mmol})$ in THF $(100 \mathrm{~mL})$ was added $\left(c-\mathrm{C}_{5} \mathrm{H}_{9}\right)_{7}$ $\mathrm{Si}_{7} \mathrm{O}_{9}(\mathrm{OH})_{3}(2.48 \mathrm{~g}, 2.8 \mathrm{mmol})$ at room temperature. Triethylamine ( $1.6 \mathrm{~mL}, 11.5 \mathrm{mmol}$ ) was then added dropwise to the resultant solution forming a white suspension. The mixture was stirred for $48 \mathrm{~h}$, filtered to remove $\mathrm{Et}_{3} \mathrm{~N}(\mathrm{H}) \mathrm{Cl}$ and evaporated. The resultant solid was then extracted with toluene and filtered to remove the last traces of $\mathrm{Et}_{3} \mathrm{~N}(\mathrm{H}) \mathrm{Cl}$. The toluene solution was evaporated to dryness and the product was stripped with hexanes $(2 \times 60 \mathrm{~mL})$ and washed with acetone to afford compound $3(2.30 \mathrm{~g}, 2.1 \mathrm{mmol}, 74 \%)$ as a free flowing white solid. Method IV: (a) 3-Chloropropyl-trisethoxysilane
(13.3 $\mathrm{mL}, 55 \mathrm{mmol})$ was added dropwise to a THF $(100 \mathrm{~mL})$ solution of FluLi, prepared in situ via reaction of fluorene $(10 \mathrm{~g}, 60 \mathrm{mmol})$ and $\mathrm{BuLi}(2.4 \mathrm{~mL}, 60 \mathrm{mmol})$. The reaction mixture was stirred at room temperature for $16 \mathrm{~h}$. Volatiles were roomed in vacuo affording a milky oil, which on the addition of hexanes produce a yellow solution and a white precipitate, believed to be $\mathrm{LiCl}$. Subsequent filtration and evaporation in vacuo gave $\left((\mathrm{EtO})_{3} \mathrm{Si}\left(\mathrm{CH}_{2}\right)_{3}\right)-9-\mathrm{Flu}(\mathrm{H})(16.0 \mathrm{~g}, 79 \%)$ as an orange oil. (b) $\left(\mathrm{C}_{5} \mathrm{H}_{9}\right)_{7} \mathrm{Si}_{7} \mathrm{O}_{9}(\mathrm{OH})_{3}(3.85 \mathrm{~g}, 4.4 \mathrm{mmol})$ was added to a stirred solution of $\left((\mathrm{EtO})_{3} \mathrm{Si}\left(\mathrm{CH}_{2}\right)_{3}\right)-9-\mathrm{Flu}(\mathrm{H})$ $(1.64 \mathrm{~g}, 4.4 \mathrm{mmol})$ in toluene $(100 \mathrm{~mL})$. Triethylamine $(0.6 \mathrm{~mL}$, $4.3 \mathrm{mmol}$ ) was added to the suspension and heated to reflux. After approximately one hour the suspension clarified, heating was continued for a further 8 days. Volatiles were removed in vacuo and the resultant product was twice dissolved in hexanes $(2 \times 20 \mathrm{~mL})$ and subsequently dried in vacuum to afford a waxy solid. The solid was freeze-dried three times to afford 3 as a free flowing solid $(2.70 \mathrm{~g}, 2.5 \mathrm{mmol}, 57 \%)$. (Found: C, 55.29; H, 7.10. $\mathrm{C}_{51} \mathrm{H}_{78} \mathrm{O}_{12} \mathrm{Si}_{8}$ requires: $\mathrm{C}, 55.05 ; \mathrm{H}$, $7.09 \%)$

$\left(\boldsymbol{c}-\mathrm{C}_{5} \mathbf{H}_{9}\right)_{7} \mathrm{Si}_{8} \mathrm{O}_{12} \mathbf{C H}_{2}-\mathbf{9}-\mathrm{Flu}\left(\mathbf{9}-\mathrm{SiMe}_{3}\right)$ (5a). Complex 2 (1.00 g, $0.93 \mathrm{mmol}$ ) was dissolved in $30 \mathrm{~mL}$ of THF and chilled to $0{ }^{\circ} \mathrm{C}$. $n$-BuLi $(0.35 \mathrm{~mL}, 2.5 \mathrm{M}$ in hexanes, $0.9 \mathrm{mmol})$ was added dropwise to the stirred solution, producing a dark cherry red solution. The solution was stirred for $0.5 \mathrm{~h}$ at which time trimethylchlorosilane $(0.13 \mathrm{~mL}, 1.0 \mathrm{mmol})$ was added affording a colorless solution. Volatiles were removed in vacuo and the remaining off-white solid was extracted with hexane. Slow evaporation of the hexane solution yielded colorless needles of 5a $(0.79$ g, 0.69 mmol, 74\%). (Found: C, 54.22; H, 7.18. $\mathrm{C}_{52} \mathrm{H}_{82} \mathrm{O}_{12} \mathrm{Si}_{9}$ requires: $\mathrm{C}, 53.98 ; \mathrm{H}, 7.21 \%$ ).

$\mathbf{C p} *\left[\left(c-\mathbf{C}_{5} \mathbf{H}_{9}\right)_{7} \mathbf{S i}_{8} \mathbf{O}_{12} \mathbf{C H}_{2}-\mathbf{9 - F l u}\right] \mathrm{ZrCl}_{2}$ (6a). Ligand $2(0.97 \mathrm{~g}$, $0.90 \mathrm{mmol}$ ) was dissolved in $30 \mathrm{~mL}$ of THF, chilled to $0{ }^{\circ} \mathrm{C}$ and $n$-BuLi $(0.35 \mathrm{~mL}, 2.5 \mathrm{M}$ in hexanes, $0.9 \mathrm{mmol})$ was added dropwise to the stirred solution, producing a dark cherry red solution. After stirring for an additional $0.5 \mathrm{~h}$, the volatiles were removed in vacuo and the resultant red solid was heated to $c a$. $50{ }^{\circ} \mathrm{C}$ for $1 \mathrm{~h}$. Toluene $(15 \mathrm{~mL})$ was added and the solution cooled to $c a$. $-80{ }^{\circ} \mathrm{C}$. $\mathrm{Cp}^{*} \mathrm{ZrCl}_{3}(0.31 \mathrm{~g}, 0.90 \mathrm{mmol})$ was added as a solid, in one portion. The suspension was allowed to slowly warm to room temperature and stirred overnight. Volatiles were then removed in vacuo to afforded $\mathbf{6 a}$ as an orange solid (1.06 g. $0.8 \mathrm{mmol}, 83 \%$ ). Crystals were grown, by slow cooling of a saturated hexane solution. (Found: C, 51.49; H, 6.45. $\mathrm{C}_{59} \mathrm{H}_{88} \mathrm{Cl}_{2} \mathrm{O}_{12} \mathrm{Si}_{10} \mathrm{Zr}$ requires: $\mathrm{C}, 50.98 ; \mathrm{H}, 6.53 \%$ ).

$\mathbf{C p} *\left[\left(c-\mathrm{C}_{5} \mathrm{H}_{9}\right)_{7} \mathrm{Si}_{8} \mathrm{O}_{12}\left(\mathrm{CH}_{2}\right)_{3}-\mathbf{9 - F l u}\right] \mathrm{ZrCl}_{2}$ (7). Ligand 3 (1.50 g, $1.35 \mathrm{mmol})$ synthesized using method II was dissolved in ca. $20 \mathrm{~mL}$ of THF, chilled to $-40{ }^{\circ} \mathrm{C}$ and $n$-BuLi $(0.54 \mathrm{~mL}$, 2.5 $\mathrm{M}$ in hexanes, $1.35 \mathrm{mmol}$ ) was added dropwise to the stirred solution, producing a dark cherry red solution. After stirring for an additional $1 \mathrm{~h}$ at $-40{ }^{\circ} \mathrm{C}$, the volatiles were removed in vacuo and the resultant red solid was heated to $c a .50{ }^{\circ} \mathrm{C}$ for $40 \mathrm{~min}$. Toluene $(15 \mathrm{~mL})$ was added and the solution cooled to ca. $-80^{\circ} \mathrm{C}$. $\mathrm{Cp}^{*} \mathrm{ZrCl}_{3}(0.55 \mathrm{~g}, 1.35 \mathrm{mmol})$ was added as a solid, in one portion. The suspension was allowed to slowly warm to room temperature and stirred overnight. Volatiles were then removed in vacuo to afforded an orange solid, which was washed with hexane $(2 \times 5 \mathrm{~mL})$. Dichloromethane $(15 \mathrm{~mL})$ was added giving a bright orange solution with a white precipitate. Filtration and slow cooling to $-30{ }^{\circ} \mathrm{C}$ of the dichloromethane solution yielded $7(0.79 \mathrm{~g}, 0.56 \mathrm{mmol}, 42 \%)$ as bright orange feather like crystals. (Found: $\mathrm{C}, 52.18 ; \mathrm{H}, 6.60 . \mathrm{C}_{61} \mathrm{H}_{92} \mathrm{Cl}_{2} \mathrm{O}_{12}-$ $\mathrm{Si}_{8} \mathrm{Zr}$ requires: $\left.\mathrm{C}, 51.84 ; \mathrm{H}, 6.58 \%\right)$.

$\mathrm{Cp}^{*}\left[\left({ }^{-}-\mathrm{C}_{5} \mathrm{H}_{9}\right)_{7} \mathrm{Si}_{8} \mathrm{O}_{12} \mathrm{C}_{6} \mathrm{H}_{4} \mathrm{CH}_{2}-\mathbf{9}-\mathrm{Flu}_{\mathrm{ZrCl}}\right.$ (8). Using the same procedure as for $\mathbf{6 a}$, with addition of $\mathrm{Cp}^{*} \mathrm{ZrCl}_{3}(0.31 \mathrm{~g}$, $0.9 \mathrm{mmol})$ yielded 8 (1.06 g. $0.8 \mathrm{mmol}, 83 \%)$ as a yellow solid. 
(Found: C, 53.76; $\mathrm{H}, 6.39 . \mathrm{C}_{65} \mathrm{H}_{92} \mathrm{Cl}_{2} \mathrm{O}_{12} \mathrm{Si}_{8} \mathrm{Zr}$ requires: C, 53.31; $\mathrm{H}, 6.43 \%)$.

$\left[\left(c-\mathbf{C}_{5} \mathbf{H}_{9}\right)_{7} \mathbf{S i}_{8} \mathbf{O}_{12} \mathbf{C H}_{2}-\mathbf{9}-\mathrm{Flu}_{2} \mathrm{ZrCl}_{2}\right.$ (9). Ligand 2 (2.94 g, $2.72 \mathrm{mmol})$ was dissolved in THF $(50 \mathrm{~mL})$ and chilled to $0{ }^{\circ} \mathrm{C}$. $n$-BuLi $(1.10 \mathrm{~mL}, 2.5 \mathrm{M}$ in hexanes, $2.7 \mathrm{mmol})$ was added dropwise to the stirred solution, producing a dark cherry red solution. After stirring for an additional $1 \mathrm{~h}$, the volatiles were removed in vacuo. Toluene $(40 \mathrm{~mL})$ was added and the solution cooled to $c a .-80{ }^{\circ} \mathrm{C} . \mathrm{ZrCl}_{4}(0.32 \mathrm{~g}, 1.37 \mathrm{mmol})$ was added as a solid, in one portion via a transfer tube. The suspension was allowed to warm to room temperature and stirred overnight Volatiles were then removed in vacuo to afford a bright red solid, which was washed with hexane $(2 \times 10 \mathrm{~mL})$. Dichloromethane $(20 \mathrm{~mL})$ was then added giving a bright red solution with a white precipitate. After filtration and concentration, the saturated dichloromethane solution was cooled to $-30{ }^{\circ} \mathrm{C}$ to yield 9 as bright red platelets $(1.34 \mathrm{~g}, 0.58 \mathrm{mmol}, 43 \%)$. (Found: C, 50.74; $\mathrm{H}, 6.34 . \mathrm{C}_{98} \mathrm{H}_{146} \mathrm{Cl}_{2} \mathrm{O}_{24} \mathrm{Si}_{16} \mathrm{Zr}$ requires: $\mathrm{C}, 50.33 ; \mathrm{H}$, $6.17 \%)$

$\mathbf{C p}^{\prime \prime}\left[\mathrm{FluCH}_{2} \mathrm{SiMe}_{2} \mathbf{O E t}\right] \mathrm{ZrCl}_{2}$ (10). (i) Ethanol (3.22g, 70 mmol) was added dropwise to a stirred solution of chloromethyl-dimethylchloro-silane $(10 \mathrm{~g}, 70 \mathrm{mmol})$ and triethylamine $(11 \mathrm{~mL}, 80 \mathrm{mmol})$ in THF $(200 \mathrm{~mL})$, upon which a white precipitate immediately formed. The resultant suspension was then heated to reflux for $2 \mathrm{~h}$. The suspension was allowed to cool and filtered to remove $\left[\mathrm{NEt}_{3} \mathrm{HCl}\right]$. The solution was fractionally distilled to afford $\mathrm{ClCH}_{2} \mathrm{SiMe}_{2} \mathrm{OEt}$ as a clear liquid (bp $404-407 \mathrm{~K}, 8.22 \mathrm{~g}, 77 \%) .{ }^{1} \mathrm{H}$ NMR $\left(\mathrm{CDCl}_{3}, \delta\right), 3.74(\mathrm{q}, 2 \mathrm{H}$, $\left.{ }^{3} \mathrm{~J}_{\mathrm{H}-\mathrm{H}}=8 \mathrm{~Hz}, \mathrm{O}-\mathrm{CH}_{2} \mathrm{CH}_{3}\right), 2.79\left(\mathrm{~s}, 2 \mathrm{H}, \mathrm{ClCH}_{2} \mathrm{Si}\right), 1.20(\mathrm{t}, 2 \mathrm{H}$, $\left.{ }^{3} J_{\mathrm{H}-\mathrm{H}}=8 \mathrm{~Hz}, \mathrm{O}-\mathrm{CH}_{2} \mathrm{CH}_{3}\right), 0.24\left(\mathrm{~s}, 6 \mathrm{H}, \mathrm{Si}-\mathrm{CH}_{3}\right) .{ }^{13} \mathrm{C}\left\{{ }^{1} \mathrm{H}\right\} \mathrm{NMR}$ $\left(\mathrm{CDCl}_{3}, \delta\right): 58.99\left(\mathrm{~s}, \mathrm{O}-\mathrm{CH}_{2} \mathrm{CH}_{3}\right), 29.59\left(\mathrm{~s}, \mathrm{ClCH} \mathrm{H}_{2} \mathrm{Si}\right), 18.43$ (s, $\mathrm{O}-\mathrm{CH}_{2} \mathrm{CH}_{3}$ ), -3.49 (s, $\mathrm{Si}-\mathrm{CH}_{3}$ ). (ii) Sodium bis(trimethylsiyl)amine $(6.04 \mathrm{~g}, 33 \mathrm{mmol})$ as a solid was added over a period of $20 \mathrm{~min}$ to a stirred solution of fluorene $(5.48 \mathrm{~g}, 33 \mathrm{mmol})$ in THF $(50 \mathrm{~mL})$. The cherry red solution was stirred for $4 \mathrm{~h}$, at which point $5 \mathrm{~g}(33 \mathrm{mmol})$ of $\mathrm{ClCH}_{2} \mathrm{SiMe}_{2} \mathrm{OEt}$ was added. Stirring was continued overnight affording a green solution (which turns yellow on exposure to air) and a clear precipitate. The volatiles were removed in vacuo yielding an oily residue. Heptane $(50 \mathrm{~mL})$ was added and the resultant suspension was filtered. The volatiles were thoroughly removed in vacuo to afford an orange oil. The oil was then vacuum transferred yielding $\mathrm{Me}_{2}(\mathrm{EtO}) \mathrm{SiCH}_{2}-9-\mathrm{Flu}(\mathrm{H})$ as an orange oil (4.93 g, $17 \mathrm{mmol}, 53 \%) .{ }^{1} \mathrm{H} \mathrm{NMR}\left(\mathrm{CDCl}_{3}, \delta\right): 7.80\left(\mathrm{~d}, 2 \mathrm{H},{ }^{3} J_{\mathrm{H}-\mathrm{H}}=7 \mathrm{~Hz}\right.$, Flu-CH $), 7.62\left(\mathrm{~d}, 2 \mathrm{H},{ }^{3} J_{\mathrm{H}-\mathrm{H}}=8 \mathrm{~Hz}, \mathrm{Flu}-\mathrm{CH}\right), 7.40(\mathrm{~m}, 4 \mathrm{H}$ Flu-CH), $4.22\left(\mathrm{t}, 1 \mathrm{H},{ }^{3} J_{\mathrm{H}-\mathrm{H}}=7 \mathrm{~Hz}\right.$, Flu-CH-9), $3.53(\mathrm{q}, 2 \mathrm{H}$, $\left.{ }^{3} \mathrm{~J}_{\mathrm{H}-\mathrm{H}}=8 \mathrm{~Hz}, \mathrm{O}-\mathrm{CH}_{2} \mathrm{CH}_{3}\right), 1.58\left(\mathrm{~d}, 2 \mathrm{H},{ }^{3} \mathrm{~J}_{\mathrm{H}-\mathrm{H}}=7 \mathrm{~Hz}\right.$, FluCH-9$\left.\mathrm{CH}_{2} \mathrm{Si}\right), 1.14\left(\mathrm{t}, 3 \mathrm{H},{ }^{3} \mathrm{~J}_{\mathrm{H}-\mathrm{H}}=8 \mathrm{~Hz}, \mathrm{O}-\mathrm{CH}_{2} \mathrm{CH}_{3}\right),-0.21(\mathrm{~s}$, $\left.\mathrm{Si}-\mathrm{CH}_{3}\right) \cdot{ }^{13} \mathrm{C}\left\{{ }^{1} \mathrm{H}\right\} \quad \mathrm{NMR}\left(\mathrm{CDCl}_{3}, \delta\right): 148.88$ (s, Flu- $\left.C_{\text {ipso }}\right)$, 140.53 (s, Flu- $\left.C_{\text {ipso }}\right), 126.85,126.79,124.64,119.70$ (s, Flu- $\mathrm{CH}$ ), 57.94 (s, O-C $\mathrm{H}_{2} \mathrm{CH}_{3}$ ), 43.19 (s, Flu-C-9), 19.84 (s, $\mathrm{O}-\mathrm{CH}_{2} \mathrm{CH}_{3}$ ), 18.39 (s, Flu- $\mathrm{CH}_{2} \mathrm{Si}$ ), $-0.93\left(\mathrm{~s}, \mathrm{Si}-\mathrm{CH}_{3}\right)$. (iii) Sodium bis(trimethylsilyl)amine $(0.45 \mathrm{~g}, 2.5 \mathrm{mmol})$ was added as a solid to a stirred solution of $\mathrm{Me}_{2}(\mathrm{EtO}) \mathrm{SiCH}_{2}-9-\mathrm{Flu}(\mathrm{H})$ $(0.69 \mathrm{~g}, 2.5 \mathrm{mmol})$ in THF $(50 \mathrm{~mL})$. The solution turned dark red and stirring was continued overnight. The THF was then removed in vacuo affording a sticky red solid. Toluene $(30 \mathrm{~mL})$ was then added and the solution cooled to $-78{ }^{\circ} \mathrm{C}$ at which point $\mathrm{Cp}^{\prime \prime} \mathrm{ZrCl}_{3}(1.0 \mathrm{~g}, 2.5 \mathrm{mmol})$ was added. The suspension was allowed to warm to room temperature and stirring continued overnight affording a yellow solution with a clear precipitate. Volatiles were removed in vacuo affording a yellow oily residue. The oil was heated to $100{ }^{\circ} \mathrm{C}$ in vacuo for a further $4 \mathrm{~h}$ to remove traces of solvent. Heptane $(20 \mathrm{~mL})$ was then added and the resultant suspension filtered. The heptane was evaporated affording a yellow low melting solid. This procedure was repeated with another three portions of heptane at which point the residue was dried in vacuo at $373 \mathrm{~K}$ for a further $3 \mathrm{~h}$ yielding
10 as a yellow solid (1.15 g, $1.8 \mathrm{mmol}, 72 \%)$. EI MS (70 eV) $\mathrm{M}^{+}$ 631. (Found: $\mathrm{C}, 55.74 ; \mathrm{H}, 6.77 . \mathrm{C}_{29} \mathrm{H}_{42} \mathrm{Cl}_{2} \mathrm{OSi}_{2} \mathrm{Zr}$ requires: $\mathrm{C}$, $55.33 ; \mathrm{H}, 6.82 \%)$.

$\mathrm{Cp}\left(\mathrm{C}_{5} \mathrm{Me}_{4} \mathrm{SiMe}_{2} \mathrm{OEt}\right) \mathrm{ZrCl}_{2}$ (11). (i) To a solution of $\mathrm{C}_{5} \mathrm{Me}_{4}(\mathrm{H}) \mathrm{SiMe}_{2} \mathrm{Cl}(2.50 \mathrm{~g}, 11.7 \mathrm{mmol})$ in THF (ca. $\left.50 \mathrm{~mL}\right)$, a THF $(40 \mathrm{~mL})$ solution of ethanol $(0.55 \mathrm{~g}, 11.7 \mathrm{mmol})$ and triethylamine $(2 \mathrm{~mL}, 14.4 \mathrm{mmol})$ was added via syringe and the reaction mixture was stirred overnight at room temperature. The ammonium chloride salt was removed by filtration under argon and the solvent was removed in vacuo. The crude product was taken up in petroleum ether $30-40(c a .40 \mathrm{~mL})$ and filtered once more to remove the remaining ammonium chloride salt. The volatiles were evaporated and the product was then warmed in vacuo at $313 \mathrm{~K}$ for a further $16 \mathrm{~h}$ to remove traces of solvent. Yield: $(2.25,10 \mathrm{mmol}, 86 \%) .{ }^{1} \mathrm{H}$ NMR $\left(\mathrm{C}_{6} \mathrm{D}_{6}, \delta\right) 3.52$ (q, $\left.2 \mathrm{H},{ }^{3} J_{\mathrm{H}-\mathrm{H}}=8 \mathrm{~Hz}, \mathrm{O}-\mathrm{CH}_{2} \mathrm{CH}_{3}\right) 2.62\left(\mathrm{~m}, 1 \mathrm{H}, \mathrm{C}_{5} \mathrm{Me}_{4}(H)-\right.$ $\left.\mathrm{SiMe}_{2} \mathrm{OEt}\right), 1.89\left(\mathrm{~s}, 6 \mathrm{H}, \mathrm{C}_{5}\left(\mathrm{CH}_{3}\right)_{4}-\right), 1.78\left(\mathrm{~s}, 6 \mathrm{H}, \mathrm{C}_{5}\left(\mathrm{CH}_{3}\right)_{4}-\right)$, $1.56\left(\mathrm{t}, 6 \mathrm{H},{ }^{3} J_{\mathrm{H}-\mathrm{H}}=8 \mathrm{~Hz}-\mathrm{SiMe}_{2} \mathrm{OCH}_{2} \mathrm{CH}_{3}\right),-0.29(\mathrm{~s}, 6 \mathrm{H}$, $\left.-\mathrm{Si}\left(\mathrm{CH}_{3}\right)_{2} \mathrm{OEt}\right) .{ }^{13} \mathrm{C}\left\{{ }^{1} \mathrm{H}\right) \mathrm{NMR}\left(\mathrm{C}_{6} \mathrm{D}_{6}, \delta\right) 55.27$ (s, - $\mathrm{SiMe}_{2} \mathrm{O}-$ $\mathrm{CH}_{2} \mathrm{CH}_{3}$ ), 41.22 (s, $\left.-\mathrm{SiMe}_{2} \mathrm{OCH}_{2} \mathrm{CH}_{3}\right), 25.50$ (s, $\left.\mathrm{CH}-\mathrm{Cp}\right)$, $13.97\left(\mathrm{~s}, \mathrm{C}_{5}\left(\mathrm{CH}_{3}\right)_{4}-\right), 11.48\left(\mathrm{~s}, \mathrm{C}_{5}\left(\mathrm{CH}_{3}\right)_{4}{ }^{-}\right),-1.23\left(\mathrm{~s},-\mathrm{Si}\left(\mathrm{CH}_{3}\right)_{2}{ }^{-}\right.$ OEt). (ii) A total of $0.85 \mathrm{~g}(3.8 \mathrm{mmol})$ of $\mathrm{C}_{5} \mathrm{Me}_{4}(\mathrm{H}) \mathrm{SiMe}_{2} \mathrm{OEt}$ as a toluene solution $(10 \mathrm{~mL})$ was added via syringe to sodium bis(trimethylsilyl)amide $(0.70 \mathrm{~g}, 3.8 \mathrm{mmol})$ dissolved in toluene $40 \mathrm{~mL}$. The mixture was stirred overnight to yield a pale red solution. The solution was cooled and $\mathrm{CpZrCl}_{3}(1.00 \mathrm{~g}$, $3.8 \mathrm{mmol}$ ) added as a solid in three portions. The suspension was stirred overnight to afford a pale green solution with a white precipitate. The volatiles were evaporated and twice the residue was dissolved in petroleum ether 30-40 and subsequently dried in vacuo. Hexane was then added and the suspension filtered hot. Volatiles were then removed to afford 11 as a pale green solid $(1.62 \mathrm{~g}, 95 \%, 3.6 \mathrm{mmol})$.

Reaction of 10 with $\left(c-\mathrm{C}_{6} \mathrm{H}_{11}\right)_{7} \mathrm{Si}_{7} \mathrm{O}_{9}(\mathrm{OH})_{3}$. Complex 10 $(0.400 \mathrm{~g}, 0.6 \mathrm{mmol})$ and $\left(c-\mathrm{C}_{5} \mathrm{H}_{9}\right)_{7} \mathrm{Si}_{7} \mathrm{O}_{9}(\mathrm{OH})_{3}(0.536 \mathrm{~g}$, $0.6 \mathrm{mmol}$ ) were charged into a vessel along with $10 \mathrm{~mL}$ of toluene. The solution was then heated to $100{ }^{\circ} \mathrm{C}$ for $16 \mathrm{~h}$, after which time the reaction was cooled and $20 \mathrm{~mL}$ of acetonitrile was added to precipitate the silsesquioxane-containing fraction. The off-white precipitate was collected and analyzed and was confirmed by ${ }^{1} \mathrm{H}$ NMR to be $\left[\left(c-\mathrm{C}_{5} \mathrm{H}_{9}\right)_{7} \mathrm{Si}_{7} \mathrm{O}_{12}\right] \mathrm{ZrCp}^{\prime \prime}(0.58 \mathrm{~g}$, $0.5 \mathrm{mmol}, 81 \%)$. ${ }^{1} \mathrm{H}$ NMR $\left(\mathrm{CDCl}_{3}, \delta\right): 6.86\left(\mathrm{t}, 1 \mathrm{H}, \mathrm{C}_{5} H_{3}-\right.$ $\left.\left(\mathrm{SiMe}_{3}\right)_{2},{ }^{4} J_{\mathrm{H}-\mathrm{H}}=2 \mathrm{~Hz}\right), 6.82\left(\mathrm{~d}, 2 \mathrm{H}, \mathrm{C}_{5} H_{3}\left(\mathrm{SiMe}_{3}\right)_{2},{ }^{4} J_{\mathrm{H}-\mathrm{H}}=\right.$ $2 \mathrm{~Hz}), 1.76\left(\mathrm{~m}, 14 \mathrm{H}, \mathrm{CH}_{2}-\mathrm{C}_{5} \mathrm{H}_{9}\right), 1.54\left(\mathrm{~m}, 42 \mathrm{H}, \mathrm{CH}_{2}-\mathrm{C}_{5} \mathrm{H}_{9}\right)$, $0.96\left(\mathrm{~m}, 7 \mathrm{H}, \mathrm{CH}-\mathrm{C}_{5} \mathrm{H}_{9}\right), 0.36\left(18 \mathrm{H}, \mathrm{C}_{5} \mathrm{H}_{3}\left(\mathrm{Si}\left(\mathrm{CH}_{3}\right)_{3}\right)_{2}\right) .{ }^{13} \mathrm{C}$ NMR $\left(\mathrm{CDCl}_{3}, \delta\right): 129.94\left(\mathrm{~s}, C_{\text {ipso }}-\mathrm{C}_{5} \mathrm{H}_{3}\left(\mathrm{SiMe}_{3}\right)_{2}\right), 128.82$ (d, $\left.C_{5} \mathrm{H}_{3}\left(\mathrm{SiMe}_{3}\right)_{2},{ }^{1} J_{\mathrm{C}-\mathrm{H}}=170 \mathrm{~Hz}\right), 123.34 \mathrm{~d}, C_{5} \mathrm{H}_{3}\left(\mathrm{SiMe}_{3}\right)_{2},{ }^{1} J_{\mathrm{C}-\mathrm{H}}=$ $168 \mathrm{~Hz}), 27.78\left(\mathrm{t}, \mathrm{CH}_{2}-\mathrm{C}_{5} \mathrm{H}_{9},{ }^{1} J_{\mathrm{C}-\mathrm{H}}=131 \mathrm{~Hz}\right), 27.34\left(\mathrm{t}, \mathrm{CH}_{2}-\right.$ $\left.\mathrm{C}_{5} \mathrm{H}_{9},{ }^{1} J_{\mathrm{C}-\mathrm{H}}=130 \mathrm{~Hz}\right), 27.11\left(\mathrm{t}, C_{2} \mathrm{H}_{2}-\mathrm{C}_{5} \mathrm{H}_{9},{ }^{1} J_{\mathrm{C}-\mathrm{H}}=129 \mathrm{~Hz}\right)$, $22.78\left(\mathrm{~d}, \mathrm{CH}-\mathrm{C}_{5} \mathrm{H}_{9},{ }^{1} J_{\mathrm{C}-\mathrm{H}}=119 \mathrm{~Hz}\right), 22.41\left(\mathrm{~d}, \mathrm{CH}-\mathrm{C}_{5} \mathrm{H}_{9},{ }^{1} J_{\mathrm{C}-\mathrm{H}}\right.$ $=117 \mathrm{~Hz}), 22.34\left(\mathrm{~d}, \mathrm{CH}-\mathrm{C}_{5} \mathrm{H}_{9},{ }^{1} J_{\mathrm{C}-\mathrm{H}}=117 \mathrm{~Hz}\right),-0.34(\mathrm{q}$, $\left.\mathrm{C}_{5} \mathrm{H}_{3}\left(\mathrm{Si}\left(\mathrm{CH}_{3}\right)_{3}\right)_{2},{ }^{1} J_{\mathrm{C}-\mathrm{H}}=119 \mathrm{~Hz}\right) .{ }^{29} \mathrm{Si}$ NMR (toluene, $\delta$ ): -9.17 $\left(\mathrm{SiMe}_{3}\right),-64.32,-66.53,-68.29(1: 3: 1: 3)$. The toluene/ acetonitrile solution was then evaporated to yield a sticky yellow oil, which when analyzed by ${ }^{1} \mathrm{H}$ NMR was found to contain the free fluorene ligand.

Reaction of 11 with $\left(c-\mathrm{C}_{6} \mathrm{H}_{11}\right)_{7} \mathrm{Si}_{7} \mathrm{O}_{9}(\mathrm{OH})_{3}$. $\mathrm{Cp}\left(\mathrm{C}_{5} \mathrm{Me}_{4} \mathrm{SiMe}_{2}-\right.$ $\mathrm{OEt}) \mathrm{ZrCl}_{2}(0.23 \mathrm{~g}, 0.5 \mathrm{mmol})$ and $\left(c-\mathrm{C}_{6} \mathrm{H}_{11}\right)_{7} \mathrm{Si}_{7} \mathrm{O}_{9}(\mathrm{OH})_{3}(0.5 \mathrm{~g}$, $0.5 \mathrm{mmol}$ ) were charged into a vessel along with $10 \mathrm{~mL}$ of toluene. The solution was then heated to $100{ }^{\circ} \mathrm{C}$ for $16 \mathrm{~h}$. Volatiles were then vacuum transfer to a separate vessel and a sample of the volatiles was treated with a few drops of aqueous $\mathrm{AgNO}_{3}$. The formation of a white dispersion proved the presence of chloride ions. Twice the white waxy residue was dissolved in heptane $(5 \mathrm{~mL})$ and subsequently evaporated. The thus obtained dry solid was analyzed by NMR and the silylethoxide moiety was found to be intact. The sample was then redissolved 
in toluene and heated for a further $24 \mathrm{~h}$ at $373 \mathrm{~K}$. Once more the volatiles were vacuum transferred and an aliquot was taken for $\mathrm{GC}$ analysis. The rest was tested again for the presence of chloride ions. The chloride test was inconclusive, though, GC showed the presence of EtOH.

Comparative acidity experiment. $\left(c-\mathrm{C}_{5} \mathrm{H}_{9}\right)_{7} \mathrm{Si}_{8} \mathrm{O}_{12} \mathrm{CH}_{2}-9$ $\mathrm{Flu}(\mathrm{H})(2)(0.50 \mathrm{~g}, 0.46 \mathrm{mmol})$ and $9-\mathrm{Me}-\mathrm{Flu}(\mathrm{H})(0.09 \mathrm{~g}, 0.49$ $\mathrm{mmol})$ were dissolved in THF $(20 \mathrm{~mL})$. The solution was chilled to $0{ }^{\circ} \mathrm{C}$ and $n$-BuLi $(0.2 \mathrm{~mL}, 2.5 \mathrm{M}$ in hexanes, $0.5 \mathrm{mmol})$ was added to the stirred solution. The reaction mixture was then allowed to warm to room temperature, producing a dark red solution. After stirring for $1 \mathrm{~h}$, the volatiles were removed in vacuo and the remaining dark red solid was dried at $50{ }^{\circ} \mathrm{C}$ in vacuo for $2 \mathrm{~h}$. The ${ }^{1} \mathrm{H}$ NMR (benzene- $d_{6}$ ) spectrum of the products exclusively showed the quartet at $4.01 \mathrm{ppm}$ assigned to the $9-\mathrm{Me}-\mathrm{Fl}(H)$ proton (literature ${ }^{22 b}$ value $5.03 \mathrm{ppm}$ ) and the singlet $(2.78 \mathrm{ppm})$ of the lithium salt of $2,\left[\left(c-\mathrm{C}_{5} \mathrm{H}_{9}\right)_{7} \mathrm{Si}_{8} \mathrm{O}_{12} \mathrm{CH}_{2}\right.$ 9-Flu]Li. The characteristic $\left(c-\mathrm{C}_{5} \mathrm{H}_{9}\right)_{7} \mathrm{Si}_{8} \mathrm{O}_{12} \mathrm{CH}_{2}-9-\mathrm{Flu}(H)$ triplet and $\left(c-\mathrm{C}_{5} \mathrm{H}_{9}\right)_{7} \mathrm{Si}_{8} \mathrm{O}_{12} \mathrm{CH}_{2}-9-\mathrm{Flu}(\mathrm{H})$ doublet were not observed.

Ethylene polymerization experiments. Ethylene polymerization experiments were carried out at room temperature in a $200 \mathrm{~mL}$ glass Büchi autoclave equipped with a mechanical stirrer. In a typical experiment, the cocatalyst (MAO, $10 \mathrm{~mL}$, $10 \mathrm{wt} . \%$ solution in toluene) was added into the ethylene presaturated autoclave charged with toluene $(85 \mathrm{~mL})$ and stirred vigorously for $5 \mathrm{~min}$ before the catalyst precursor was injected $(10 \mu \mathrm{mol} \mathrm{Zr}$, in $5 \mathrm{~mL}$ toluene). After the addition the pressure of ethylene was increased to $2 \mathrm{~atm}$. After $10 \mathrm{~min}$, the polymerization was terminated via addition of methanol. The polymer, methanol and toluene mixture was carefully poured into a vessel containing hydrochloric acid. The subsequent mixture was then filtered, washed with methanol and dried overnight at $90{ }^{\circ} \mathrm{C}$

\section{Acknowledgements}

This work was financed by DSM Research B.V. and the Dutch Polymer Institute (R. D., J. R. S.). D. D. E. and A. L. S thank the Council for Chemical Sciences and The Netherlands Organization for Scientific Research for a financial contribution.

\section{References}

1 O. Olabisi, M. Atiqullah and W. Kaminsky, Macromol. Chem. Phys., 1997, C37, 519; G. G. Hlatky, Chem. Rev., 2000, 100, 1347; G. Fink, B. Steinmetz, J. Zechlin, C. Przybyla and B. Tesche, Chem. Rev., 2000, 100, 1377; E. M. Carnahan and G. B. Jacobsen, CatTech., $2000,4,74$.

2 K. D. Hungenberg, J. Kerth, F. Langhauser, B. Marczinke and R. Schlund, in Ziegler Catalysts, ed. G. Fink, R. Mülhaupt and H. H. Brintzinger, Springer-Verlag, New York, 1995, ch. 20.

3 G. W. Coates, Chem. Rev., 2000, 100, 1223; L. Resconi, L. Cavallo, A. Fait and F. Piemontesi, Chem. Rev., 2000, 100, 1253; W. Kaminsky and G. Schupfner, Macromol. Symp., 2002, 177, 61 S. Lin and R. M. Waymouth, Acc. Chem. Res., 2002, 35, 765 F. J. Gómez and R. M. Waymouth, Science, 2002, 295, 635.

4 J. C. W. Chien and D. He, J. Polym. Sci., Part A: Polym. Chem., 1991, 29, 1603; S. Collins, W. M. Kelly and D. A. Holden, Marcomolecules, 1992, 25, 1780; K. Soga and M. Kaminaka, Makromol. Chem., Rapid Commun., 1992, 13, 221; K. Soga and M. Kaminaka, Makromol. Chem., 1993, 194, 1745; W. Kaminsky and F. Renner, Makromol. Chem., Rapid Commun., 1993, 14, 239; C. Janiak and B. Rieger, Angew. Makromol. Chem., 1994, 47, 215; M. C. Sacchi, D. Zucchi, I. Titto, P. Locatelli and T. Dall'Occo, Macromol. Rapid Commun., 1995, 16, 581; T. Kamfjord, T. S. Wester and E. Rytter, Macromol. Rapid Commun., 1998, 19, 505; J. C. W. Chien, Top. Catal., 1999, 7, 23; M. O. Kristen, Top. Catal., 1999, 7, 89; M. Stork, A. Hermann, T. Nemnich, M. Klapper and K. Müllen, Angew. Chem. Int. Ed., 2000, 39, 4367; S. J. Obrey and A. R. Barron, Macromolecules, 2002, 35, 1499.
5 M. Bochmann, J. Pindado and S. J. Lancaster, J. Mol. Catal. A Chem., 1999, 146, 179; J. Walzer and J. Flexer, US Pat., 5972823, 1999; D. G. Ward and E. M. Carnahan, PCT Pat., WO96/23005, 1996; S. Charoenchaidet, S. Chavadej and E. Gulari, J. Polym. Sci., Part A: Polym. Chem., 2002, 40, 3240; S. Charoenchaidet, S. Chavadej and E. Gulari, Macromol. Rapid Commun., 2002, 23, 426; K. Musikabhumma, T. P. Spaniol and J. Okuda, Macromol. Chem. Phys, 2002, 203, 115.

6 H. W. Turner, U.S. Pat., 5427 991, 1995; S. Hinokuma, S. Miyake, M. Ono and S. Inazawa, Eur. Pat., 0775707 B1, 1996; G. B. Jacobsen, P. Wijkens, J. T. B. H. Jastrzebski and G. van Koten, PCT. Pat., WO96/28480, 1996; E. M. Carnahan, M. J. Carney, D. R. Neithamer, P. N. Nickias, K. Y. Shih and L. Spencer, PCT Pat., WO97/19959, 1997.

7 D.-H. Lee and K.-B. Yoon, Macromol. Rapid Commun., 1997, 18, 427; E. I. Iiskola, S. Timonen, T. T. Pakkanen, O. Härkki and J. V. Seppälä, Appl. Surf. Sci., 1997, 121/122, 372; E. I. Iiskola, S. Timonen, T. T. Pakkanen, O. Härkki, P. Lehmus and J. V. Seppälä, Macromolecules, 1997, 30, 2853; L. Gila, A. Proto, E. Ballato, D. Vigliarolo and G. Lugli, Eur. Pat., 0808841, 1997; W. M. Vega, P. L. Cañas, A. M.-E. Lafuente, G. H. Llinas, J. S. Royo and L. M. Llatas, US Pat., 5824 620, 1998; H. G. Alt, P. Schertl and A. Köppl, J. Organomet. Chem., 1998, 568, 263; S. Timonen, T. T. Pakkanen and E. I. Iiskola, J. Organomet. Chem., 1999, 582, 273; S. Timonen, T. T. Pakkanen and E. I. Iiskola, J. Mol. Catal. A: Chem., 1999, 148, 235; H. Juvaste, E. I. Iiskola and T. T. Pakkanen, J. Mol. Catal. A: Chem., 1999, 150, 1; H. Juvaste and T. T. Pakkanen, Organometallics, 2000, 19, 1729; A.-M. Uusitalo, T. T. Pakkanen and E. I. Iiskola, J. Mol. Catal. A: Chem., 2000, 156, 181; H. Schneider, G. T. Puchta, F. A. R. Kaul, G. Raudaschl-Sieber, F. Lefebvre, G. Saggio, D. Mihalios, W. Herrmann and J.-M. Basset, J. Mol. Catal. A: Chem., 2001, 170, 127; N. Médard, J. C. Soutif, I. Lado, C. Esteyries and F. Poncin-Epaillard, Macromol. Chem. Phys., 2001, 3606; F. Bortolussi, C. Boisson, R. Spitz, J. Malinge and J. P. Broyer, PCT Pat., WO 0888195, 2002.

8 R. Jackson, D. J. Ruddlesden and R. Whelan, J. Organomet. Chem., 1977, 125, 57; B. L. Booth, G. C. Ofunne, C. Stacey and P. J. T. Tait, J. Organomet. Chem., 1986, 315, 143; M. Antberg, H. Luker and L. Böhm, US Pat., 5202 398, 1993; M. Galan-Fereres, T. Koch, E. Hey-Hawkins and M. S. Eisen, J. Organomet. Chem., 1999, 580, 145; B. Lee and J. S. Oh, Macromolecules, 2000, 33, 3194; J. Tian, Y. Soo-Ko, R. Metcalfe, Y. Feng and S. Collins, Macromolecules, 2001, 34, 3120; F. A. Kaul, G. T. Puchta, H. Schneider, F. Bielert, D. Mihalios and W. A. Hermann, Organometallics, 2002, 21, 74; J. S. Oh and B. Y. Lee, US Pat., 6355 742, 2002; N. Suzuki, J. Yu, N. Shioda, H. Asami, T. Nakamura, T. Huhn, A. Fukuoka, M. Ichikawa, M. Saburi and Y. Wakatsuki, Appl. Catal. A: Gen., 2002, 224, 63

9 T. Kitagawa, T. Uozumi, K. Soga and T. Takata, Polymer, 1997, 38, 615; M. C. W. Chan, K. C. Chew, C. I. Dalby, V. C. Gibson, A. Kohlmann, I. R. Little and W. Reed, Chem. Commun., 1998, 1673; A. G. M. Barrett and Y. R. de Miguel, Chem. Commun., 1998, 2079; S. C. Hong, T. Teranishi and K. Soga, Polymer, 1998, 39, 7153; M. Stork, M. Koch, M. Klapper, K. Müllen, H. Gregorius and U. Rief, Macromol. Rapid Commun., 1999, 20, 210; H. Zhu, G.-X. Jin and N. Hu, J. Organomet. Chem., 2002, 655, 161.

10 R. Murugavel, A. Voigt, M. G. Walawalkar and H. W. Roesky, Chem. Rev., 1996, 96, 2205; S. K. Noh, S. Kim, J. Kim, D.-H. Lee, K.-B. Yoon, H.-B. Lee, S. W. Lee and W. S. Huh, J. Polym. Sci., Part A: Polym. Chem., 1997, 35, 3717.

11 R. Duchateau, Chem. Rev., 2002, 102, 3525; F. J. Feher, D. A. Newman and J. F. Walzer, J. Am. Chem. Soc., 1989, 111, 1741; F. J. Feher and D. A. Newman, J. Am. Chem. Soc., 1990, 112, 1931; F. J. Feher, T. A. Budzichowski, K. Rahimian and J. W. Ziller, J. Am. Chem. Soc., 1992, 113, 3859; T. W. Dijkstra, R. Duchateau, R. A. van Santen, A. Meetsma and G. P. A. Yap, J. Am. Chem. Soc., 2002, 124, 9856.

12 F. J. Feher, T. A. Budzichowski and K. J. Weller, J. Am. Chem. Soc., 1989, 111, 7288; F. J. Feher and K. J. Weller, Organometallics, 1990, 9, 2638; F. J. Feher, T. A. Budzichowski and J. W. Ziller, Inorg. Chem., 1992, 31, 5100; F. J. Feher, K. J. Weller and J. W. Ziller, J. Am. Chem. Soc., 1992, 114, 9686; F. J. Feher, T. A. Budzichowski and J. W Ziller, Inorg. Chem., 1997, 36, 4082; F. T. Edelmann, Y. K. Gun'ko, S. Giessmann and F. Olbrich, Inorg. Chem., 1999, 38, 210; R. Duchateau, R. J. Harmsen, H. C. L. Abbenhuis, R. A. van Santen, A. Meetsma, S. K.-H. Thiele and M. Kranenburg, Chem. Eur. J., 1999, 5, 3130; M. D. Skowronska-Ptasinska, R. Duchateau, R. A. van Santen and G. P. A. Yap, Eur. J. Inorg. Chem., 2001, 133; M. D. Skowronska-Ptasinska, R. Duchateau, R. A. van Santen and G. P. A. Yap, Organometallics, 2001, 20, 3519.

13 R. Duchateau, R. A. van Santen and G. P. A. Yap, Organometallics, 2000, 19, 809; R. A. Metcalfe, D. I. Kreller, J. Tian, H. Kim, 
N. J. Taylor, J. F. Corrigan and S. Collins, Organometallics, 2002, 21, 1719; N. Milot, A. Cox, C. C. Santini, Y. Molard and J.-M. Basset, Chem. Eur. J., 2002, 8, 1438

14 R. Duchateau, H. C. L. Abbenhuis, R. A. van Santen, A. Meetsma S. K.-H. Thiele and M. F. H. van Tol, Organometallics, 1998, 17 , 5663; R. Duchateau, U. Cremer, R. J. Harmsen, S. I. Mohamud, H. C. L. Abbenhuis, R. A. van Santen, A. Meetsma, S. K.-H. Thiele, M. F. H. van Tol and M. Kranenburg, Organometallics, 1999, 18, 5447; F. T. Edelmann, S. Giessmann and A. Fischer, Chem. Commun., 2000, 2153.

15 F. J. Feher and R. L. Blanski, J. Chem. Soc., Chem. Commun., 1990, 1614; F. J. Feher, J. F. Walzer and R. L. Blanski, J. Am. Chem. Soc., 1991, 114, 3618; J.-C. Liu, J. Chem. Soc., Chem. Commun., 1996, 1109.

16 J. R. Severn, R. Duchateau, R. A. van Santen, D. D. Ellis and A. L. Spek, Organometallics, 2002, $21,4$.

17 U. Deschler, P. Kleinschmit and P. Panster, Angew. Chem., 1986, 98, 237; P. M. Price, J. H. Clark and D. J. Macquarrie, J. Chem. Soc., Dalton Trans., 2000, 101.

18 F. J. Feher, K. Rahimian, T. A. Budzichowski and J. W. Ziller, Organometallics, 1995, 14, 3920; V. W. Day, W. G. Klemperer, V. V. Mainz and D. M. Milar, J. Am. Chem. Soc., 1985, 107, 8262.

19 M. E. Bowen, B. R. Aavula and E. A. Mash, J. Org. Chem., 2002, 67 , 9087.

20 V. B. Ribakov, V. M. Ionov, K. A. Paseshnichenko, L. A. Aslanov, A. N. Kashin and I. P. Beletskaya, Izv. Akad. Nauk. SSSR, Ser Khim., 1980, 2054
21 F. J. Feher and T. A. Budzichowski, J. Organomet. Chem., 1989, 379, 33; F. J. Feher and T. J. Tajima, J. Am. Chem. Soc., 1994, 116, 2145

22 S. Ya. Knjazhanski, G. Moreno, G. Cadenas, V. K. Belsky and B. M. Bulychev, Tetrahedron, 1999, 55, 1639 .

23 H. G. Alt and E. Samuel, Chem. Soc. Rev., 1998, 323; M. A. Schmidt, H. G. Alt and W. Milius, J. Organomet. Chem., 1996, 525, 15 .

24 P. B. Hitchcock, M. F. Lappert, G. A. Lawless, H. Oliver and E. J. Ryan, J. Chem. Soc., Chem. Commun., 1992, 474.

25 R. D. Rogers, M. M. Benning, L. K. Kurihara, K. J. Moriarti and M. D. Rausch, J. Organomet. Chem., 1985, 293, 51.

26 M. H. Lee, J.-W. Park, C. S. Hong, S. I. Woo and Y. Do, J. Organomet. Chem., 1998, 561, 37.

27 I. E. Buys, T. W. Hambley, D. J. Houlton, T. Maschmeyer, A. F. Masters and A. K. Smith, J. Mol. Catal., 1994, 86, 309; F. T. Edelmann, S. Giessmann and A. Fischer, J. Organomet. Chem., 2001, 620, 80

28 H. Makio, K. Koo and T. J. Marks, Macromolecules, 2001, 34, 4676; K. Koo, P. F. Fu and T. J. Marks, Macromolecules, 1999, 121, 8791; K. Koo and T. J. Marks, J. Am. Chem. Soc., 1999, 121, 8791; K. Koo and T. J. Marks, J. Am. Chem. Soc., 1998, 120, 4019; P. F. Fu and T. J. Marks, J. Am. Chem. Soc., 1995, 117, 10747.

29 K. Soga, H.-T. Ban, T. Arai and T. Uozumi, Macromol. Chem. Phys., 1997, 198(9), 2779 .

30 C. H. Winter, X.-X. Zhou, D. A. Dobbs and M. J. Heeg, Organometallics, 1991, 10, 210. 